\title{
The combined effect of food additive titanium dioxide and lipopolysaccharide on mouse intestinal barrier function after chronic exposure of titanium dioxide- contained feedstuffs
}

\author{
Yongliang Zhang ${ }^{1}$, Shumin Duan', Ying Liu ${ }^{2}$ and Yun Wang ${ }^{1 *}$ (i)
}

\begin{abstract}
Objective: Up to $44 \%$ of particulates of food-grade titanium dioxide $\left(\mathrm{TiO}_{2}\right)$ are in nanoscale, while the effect and combined effect of which with other substances on intestinal barrier haven't been fully understood yet. This study is aimed to study the effect of two kinds of $\mathrm{TiO}_{2}$ nanoparticles $\left(\mathrm{TiO}_{2} \mathrm{NPs}\right.$ and $\mathrm{TiO}_{2} \mathrm{MPs}$ ) on intestinal barrier functions, to reveal the combined effect of $\mathrm{TiO}_{2} \mathrm{NPs}$ and Lipopolysaccharide (LPS) on intestinal barrier.

Methods: Male ICR mice were randomly divided into 18 groups (3 feed types * 3 exposure length * 2 LPS dosage) and were fed with normal or $\mathrm{TiO}_{2}$-mixed feed (containing $1 \%$ (mass fraction, w/w) $\mathrm{TiO}_{2} \mathrm{NPs}$ or $\mathrm{TiO}_{2} \mathrm{MPs}$ ) for 1, 3, 6 months, followed by a single oral administration of 0 or $10 \mathrm{mg} /(\mathrm{kg}$ body weight) LPS. Four hours later, the transportation of $\mathrm{TiO}_{2}$, the intestinal barrier functions and the inflammatory response were evaluated.

Results: Both $\mathrm{TiO}_{2}$ notably increased the intestinal villi height / crypt depth ratios after 1 and 3 months of exposure, and increased the expression of ileal tight junction proteins (ZO-1 and occludin) after 1 month of exposure. After 6 months of exposure, $\mathrm{TiO}_{2} \mathrm{NPs}$ led to reduced feed consumption, $\mathrm{TiO}_{2} \mathrm{MPs}_{\mathrm{S}}$ caused spare microvilli in small intestine and elevated Ti content in the blood cells. The intestinal permeability didn't change in both $\mathrm{TiO}_{2}$ exposed groups. After LPS administration, we observed altered intestinal villi height / crypt depth ratios, lowered intestinal permeability (DAO) and upregulated expression of ileal $\mathrm{ZO}-1$ in both $\left(\mathrm{TiO}_{2}+\mathrm{LPS}\right)$ exposed groups. There are no significant changes of ileal or serum cytokines except for a higher serum TNF-a level in LPS treated group. The antagonistic effect was found between $\mathrm{TiO}_{2} \mathrm{NPs}$ and LPS, but there are complicated interactions between $\mathrm{TiO}_{2}$ MPs and LPS.

Conclusion: Long-term intake of food additive $\mathrm{TiO}_{2}$ could alter the intestinal epithelial structure without influencing intestinal barrier function. Co-exposure of $\mathrm{TiO}_{2}$ and $\mathrm{LPS}$ would enhance intestinal barrier function without causing notable inflammatory responses, and there is antagonistic effect between $\mathrm{TiO}_{2} \mathrm{NPs}$ and LPS. All the minor effects observed might associate with the gentle exposure method where $\mathrm{TiO}_{2}$ being ingested with feed.
\end{abstract}

Keywords: Titanium dioxide nanoparticle, Lipopolysaccharide, Nutrient absorption, Gut barrier, Inflammation

\footnotetext{
* Correspondence: wangyun@bjmu.edu.cn

'Department of Occupational and Environmental Health Sciences, School of Public Health, Peking University, Beijing 100191, People's Republic of China

Full list of author information is available at the end of the article
} 


\section{Background}

Titanium dioxide $\left(\mathrm{TiO}_{2}\right)$ is an important inorganic white pigment, and is widely used as an additive in food sector, including meat, minced fish, candy, bakery, cheese, sugar, spices, and food supplements. Considering the differences in eating habits, the daily $\mathrm{TiO}_{2}$ intake fluctuated between 0 and $112 \mathrm{mg} /$ person $[1,2]$. As $\mathrm{TiO}_{2}$ has the highest concentrations in candy, chewing gum and chocolate, children became the high exposure crowd. In 2012, it was estimated that the intake of $\mathrm{TiO}_{2}$ for every UK child under the age of 10 is 2 to $3 \mathrm{mg} / \mathrm{kg}$ per day, and every adult ingests $1 \mathrm{mg} / \mathrm{kg} \mathrm{TiO}_{2}$ a day [3]. With the development of nanotechnology, a large number of nanoscale $\mathrm{TiO}_{2}$ have been produced and used. Studies have shown that $17-36 \%[4,5]$ of food grade $\mathrm{TiO}_{2}$ particles are in nano-size, the variation is probably caused by different manufacturing methods. It was also reported that $\mathrm{TiO}_{2}$ particles extracted from commercial foods have $10-44 \%$ particles in nano-size $[1,6]$. These $\mathrm{TiO}_{2}$ NPs can be ingested with food, which will lead to direct exposure of the digestive tract to $\mathrm{TiO}_{2}$ nanoparticles (NPs).

The intestinal tract is the main site for water and nutrients absorption, and is also an important barrier against invasions of foreign materials. These functions mainly depend on the integrity of the intestinal epithelial cell barrier, which is composed of intestinal epithelial cells and intercellular connections. In the intact intestinal barrier epithelium, the intercellular space is sealed by the apical junction complex, including tight junction which closes gaps between cells [710]. The body can directly regulate the permeability of the intestinal barrier by regulating the function of tight junction which consists of a variety of proteins, like occludin, claudin, zonula occludens ( $\mathrm{ZO})$, and myosin light chain kinase [11-14]. Mild mucosal epithelial damage may promote foreign materials to cross intestinal mucosal epithelium, which in turn may induce $\mathrm{T}$ helper cell 1 (Th1) or Th2 mediated inflammatory response characterized by increased level of tumor necrosis factor (TNF), interferon- $\gamma$ (IFN- $\gamma$ ) and interleukin-13 (IL-13), these cytokines can impact on tight junction proteins and increase tight junction permeability which will allow more bacterial products or food antigens to cross the intestinal barrier [9, 13, 15]. This feedback will amplify inflammation and eventually leads to disease. Conversely, if the foreign materials triggered the differentiation of regulatory $\mathrm{T}$ (Treg) cells, intestinal mucosal hemostasis will be promoted as Th-1 cell differentiation would be suppressed, in addition, IL-10 and transforming growth factor $\beta$ (TGF- $\beta$ ) secreted by Treg cells and retinoic acid secreted by epithelial cells would enhance tight junction integrity and maintain intestinal mucosal hemostasis [15].

Acute and subchronic oral toxicity studies have shown that the bioavailability of $\mathrm{TiO}_{2}$ NPs in gastrointestinal tract is very low and most of the ingested $\mathrm{TiO}_{2}$ NPs are excreted with feces [16-19], suggesting that after being orally ingested, most of the ingested $\mathrm{TiO}_{2}$ NPs would move through the gastrointestinal tract, making the gastrointestinal tract one of its main target organs. In vitro studies have revealed that $\mathrm{TiO}_{2}$ NPs exposure can directly damage intestinal epithelial microvilli and compromise the integrity of Caco- 2 cell monolayer, including the intercellular connections [20, 21]. Our earlier in vivo research [22] also found that oral exposure to $\mathrm{TiO}_{2}$ NPs could downregulate the plasma D-lactate level and the activity of diamine oxidase (DAO), implicating its potential to affect intestinal permeability. Inflammation is an important mechanism for toxic effects caused by nanomaterials, including $\mathrm{TiO}_{2}$ NPs. Nogueira et al [23] set up a 10-day oral-exposure study and found that $\mathrm{TiO}_{2}$ NPs induced Th1 cells dominated inflammatory response in the small intestine, the ileum showed the most sever inflammatory response among all the segments of the small intestine. Inflammatory response is associated with downregulated expression of tight junction proteins [24-28], which may further increased epithelial permeability and health risks. Though it's unclear yet whether $\mathrm{TiO}_{2}$ NPs would impair intestine barrier function by inducing inflammation or not. On the other hand, it's easy for the ingested $\mathrm{TiO}_{2}$ NPs to engage with other substances in gut, like lipopolysaccharide (LPS) from bacteria. Several in vitro studies [29, 30] have already indicated co-exposure of $\mathrm{TiO}_{2}$ NPs and LPS may trigger severer inflammatory response, suggesting the potential of $\mathrm{TiO}_{2}$ NPs to interact with LPS and affect gut functions, but these findings still need to be verified in vivo.

So far, there is still limited number of in vivo studies over $\mathrm{TiO}_{2}$ NPs influencing intestinal functions, and most of them are confined to evaluating the capability of $\mathrm{TiO}_{2}$ NPs to cross the intestinal mucous membrane and accumulate in or impact on other organs [16, 31, 32]. Furthermore, these in vivo studies adopted oral gavage where $\mathrm{TiO}_{2}$ particles were suspended in liquid medium and administrated intensively, which is not in accordance with the experience of human where $\mathrm{TiO}_{2}$ particles are being ingested in milder ways, like multiple food or drug intakes. In addition, the dosage is usually high and the exposure time is usually short, with a maximum exposure period up to 90 days $[17,18,31,33,34]$. While the public typically have a low $\mathrm{TiO}_{2}$ NPs dosage and a long exposure period, so, the chronic toxicity profiles of $\mathrm{TiO}_{2}$ NPs still need to be supplemented. 
For these considerations, we simulated human exposure scenarios by mixing $\mathrm{TiO}_{2} \mathrm{NPs}$ into feeds and feeding it to mice for up to 6 months, aiming at exploring the chronic effect of $\mathrm{TiO}_{2}$ NPs on intestinal barrier. Furthermore, we attempted to verify whether long term exposure to $\mathrm{TiO}_{2}$ NPs would exacerbate the impact of bacterial toxins (Lipopolysaccharides, LPS) on intestine barrier.

\section{Results}

\section{Physiochemical properties of titanium dioxide}

As shown in Fig. 1, the two $\mathrm{TiO}_{2}$ nanoparticles $\left(\mathrm{TiO}_{2}\right.$ NPs and $\mathrm{TiO}_{2} \mathrm{MPs}$ ) both had the nearly spherical shape. $\mathrm{TiO}_{2}$ NPs was in anatase form and $\mathrm{TiO}_{2}$ MPs was in rutile form as tested by X-ray powder diffractometry (XRD). The purities were both over 99.95\% (Impurity elements were presented in the Additional file 1: Table S1). The average primary diameters of $\mathrm{TiO}_{2} \mathrm{NPs}$ and $\mathrm{TiO}_{2}$ MPs measured by transmission electron microscopy $($ TEM) were $(33.6 \pm 11.5) \mathrm{nm}$ and $(124.5 \pm 46.1)$ $\mathrm{nm}$ respectively, and the Brunauer-Emmett-Teller (BET)-specific surface area were $61.87 \mathrm{~m}^{2} / \mathrm{g}$ and $9.35 \mathrm{~m}^{2} /$ $\mathrm{g}$ respectively.

According to characterization of food additive $\mathrm{TiO}_{2}$ (E171) purchased from Chinese and European vendors, E171 was a mixture of micron-sized particles and nanosized particles (NPs) with anatase, rutile, or anatase/rutile-mixed form [35]. The diameter of E171 ranged from a

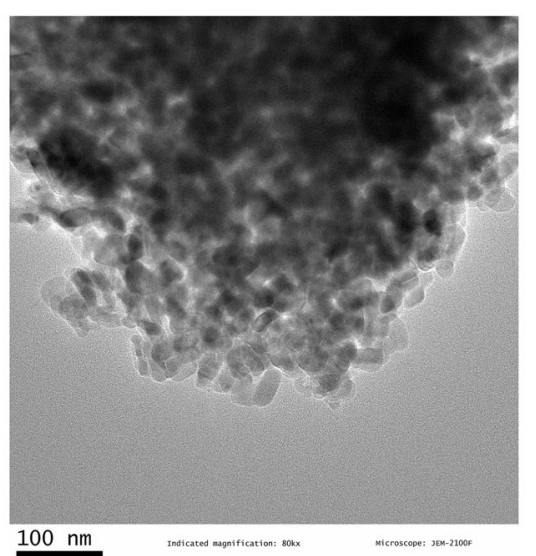

$\mathrm{C}$

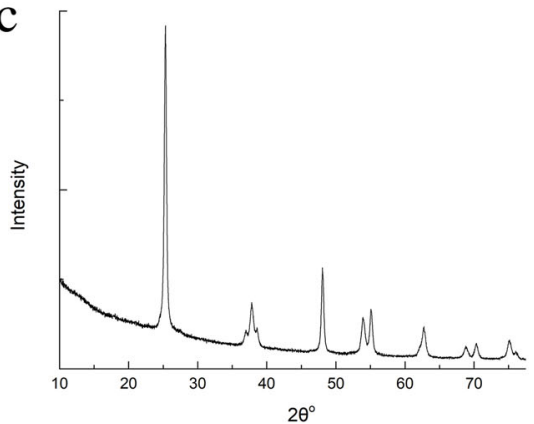

e

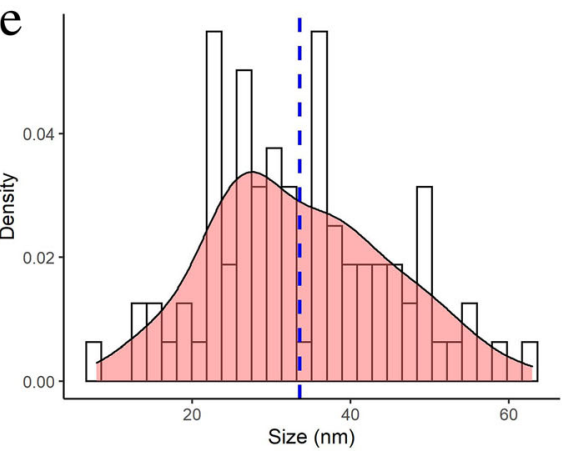

b

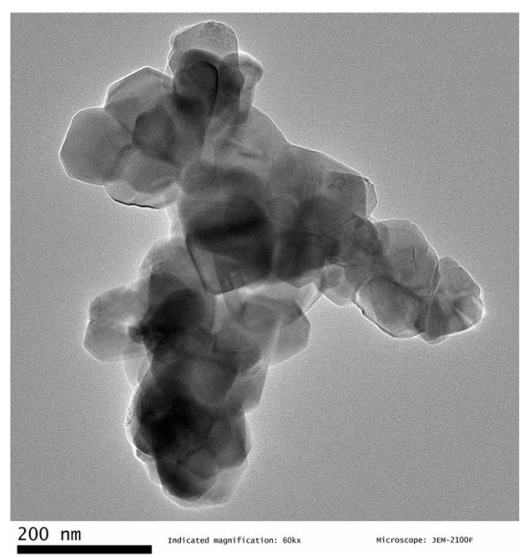

d

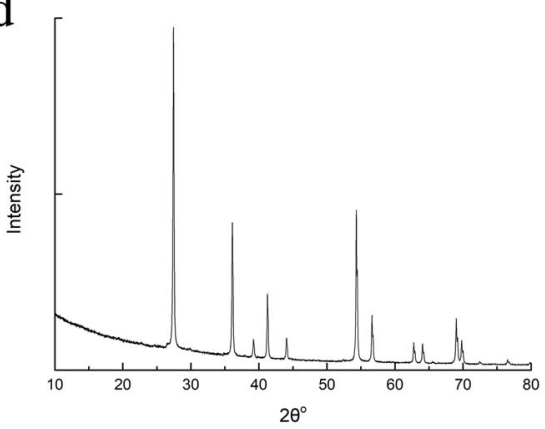

f

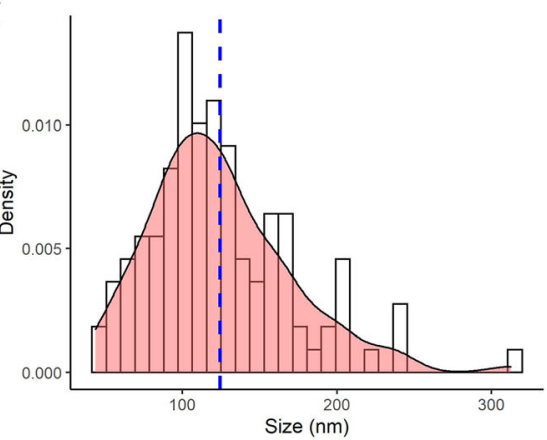

Fig. 1 TEM images, XRD images and TEM based size distributions of $\mathrm{TiO}_{2} \mathrm{NPs}(\mathbf{a}, \mathbf{c}, \mathbf{e})$ and $\mathrm{TiO}_{2} \mathrm{MPs}(\mathbf{b}, \mathbf{d}, \mathbf{f})$ 
40 to $200 \mathrm{~nm}$ with $10-36 \%$ particles in nanoscale $[1,5$, 36], which makes it difficult to explain whether the biological effects of E171 depends on its nano-fraction, micro-fraction, or the interaction of the two fractions. However, nano-fraction has attracted more attention since nanoparticles could exhibit completely different physiochemical properties as well as different biological impacts compared to their native bulk compounds. Hence, anatase $\mathrm{TiO}_{2}$ NPs and rutile $\mathrm{TiO}_{2}$ MPs which had relatively uniform particle sizes were used in this study to represent the different crystal components of food additive $\mathrm{TiO}_{2}$ E171 within nanoscale and help us to understand the health risk of nano-fraction of E171 [35].

Different from previous studies that dispersed $\mathrm{TiO}_{2}$ in ultrapure water for exposure via oral gavage, we mixed $\mathrm{TiO}_{2}$ into feed and fed it to mice for exposure. To compare the characteristic changes of the $\mathrm{TiO}_{2}$ particles ingested via oral gavage and via mixed feed in the gastrointestinal tract, the hydrodynamic diameters, polydispersity index (PDI), and zeta potential were tested carefully when the particles and particle-mixed feeds were dispersed or digested in ultrapure water $\left(\mathrm{H}_{2} \mathrm{O}\right)$, artificial gastric juice (AGJ) and artificial intestinal juice (AIJ). As shown in Table 1, both $\mathrm{TiO}_{2}$ would aggregate into larger particles in $\mathrm{H}_{2} \mathrm{O}$, AGJ and $\mathrm{AIJ}$, with the biggest hydrodynamic diameters and the worst dispersion stability in the AGJ. We also found the particles in feeds aggregated into the biggest particles in AGJ but the smallest particles in AIJ after the feeds were digested in AGJ for $2 \mathrm{~h}$ and further in AIJ for a $2.5 \mathrm{~h}$. These results suggested that $\mathrm{TiO}_{2}$ ingested via the two exposure routes presented different physiochemical properties in the gastrointestinal tract, which would result in different biological effects.

\section{Animal behavior, body weight and feed consumption}

During the animal experimental period of 6 months, only one mouse in $\mathrm{TiO}_{2}$ NPs exposed groups showed anal swelling on the 43th day and died of intestinal obstruction two days later, all other mice showed no abnormality.

As shown in Fig. 2a, though with fluctuation, body weights of mice in either control, $\mathrm{TiO}_{2} \mathrm{NPs}$ exposed group or $\mathrm{TiO}_{2} \mathrm{MPs}$ exposed group continued to increase since exposure and remained stable from the 17th week onwards. No statistically significant differences in body weight were found between the control group, $\mathrm{TiO}_{2} \mathrm{NPs}$ exposed group and $\mathrm{TiO}_{2}$ MPs exposed group during the exposure period of 6 months, except for the reduced body weight in $\mathrm{TiO}_{2}$ MPs exposed group by the end of the 2nd week when compared to control group.

We observed notable change of daily feed intake in $\mathrm{TiO}_{2}$ NPs exposed group. Comparing to control group, daily feed intake of mice in $\mathrm{TiO}_{2} \mathrm{NPs}$ exposed group decreased in the 7th, 14th, 16th and 18th week, while no significant change was observed in $\mathrm{TiO}_{2}$ MPs exposed group (Fig. 2b). We also found that daily feed intake of mice in $\mathrm{TiO}_{2}$ NPs exposed group is lower than that of $\mathrm{TiO}_{2}$ MPs exposed group in several interval weeks. When feed up to 6 months, the average daily feed intake per mouse in $\mathrm{TiO}_{2}$ NPs exposed group significantly reduced compared to control group and $\mathrm{TiO}_{2}$ MPs exposed group (Fig. 2c).

\section{Bio-transport of ingested $\mathrm{TiO}_{2}$}

During exposure, mice in both $\mathrm{TiO}_{2}$ exposed groups started excreting white feces from the 3rd week of exposure onwards (Fig. 3a), indicating that $\mathrm{TiO}_{2}$ were excreted via feces. Although $\mathrm{TiO}_{2}$ particles were observed in the intestinal epithelial cell cytoplasm in both $\mathrm{TiO}_{2}$ NPs and $\mathrm{TiO}_{2}$ MPs exposed groups (Fig. 3b, further introduced below), the increased Ti content in blood cells was only found in the $\mathrm{TiO}_{2}$ MPs exposed group after 6 months of exposure (Fig. 3c).

\section{Intestinal permeability}

Levels of serum LPS, D-lactate and DAO were detected to evaluate the permeability of the intestinal barrier. As shown in Fig. 4, significant changes were found in LPS and DAO but not in D-lactate. No differences were observed when comparing these indexes in $\mathrm{TiO}_{2} \mathrm{NPs}$ or $\mathrm{TiO}_{2}$ MPs exposed groups with control groups. However, a significant decrease in serum DAO was found in the LPS exposed group in the 6th month (see exposure group in Table 2), lower DAO levels were found in $\left(\mathrm{TiO}_{2} \mathrm{NPs}+\mathrm{LPS}\right)$ exposed group at the 3rd and the 6th month, we also observed lower LPS and DAO levels in $\left(\mathrm{TiO}_{2} \mathrm{MPs}+\mathrm{LPS}\right)$ group at the 3rd month. The serum DAO level in $\left(\mathrm{TiO}_{2} \mathrm{NPs}+\right.$ LPS $)$ exposed group was also notably lower than in $\mathrm{TiO}_{2}$ NPs exposed group at the 3rd and the 6th month. Through interaction analysis (Table 3), we only observed an antagonistic interaction between $\mathrm{TiO}_{2} \quad$ MPs and LPS at the 6th month over serum DAO, no interaction was observed between $\mathrm{TiO}_{2}$ NPs and LPS over intestinal permeability.

Collectively, $\mathrm{TiO}_{2} \mathrm{NPs}$ or $\mathrm{TiO}_{2}$ MPs exposure did not influence intestinal permeability, LPS stimulation following $\mathrm{TiO}_{2}$ exposure reduced intestinal permeability.

\section{Intestinal histopathological examination}

In control group at each time interval, intestinal villi of duodenum, jejunum and ileum are all long and intact, the intestinal cells are well lined up, structures of intestinal crypts are clear, no hyperaemia, edema or inflammatory cell infiltration were observed in all the small intestine segments. No abnormality was observed in $\mathrm{TiO}_{2}$ NPs exposed group or $\mathrm{TiO}_{2}$ MPs exposed group except for increased eosinophil in both groups at the 1st, 


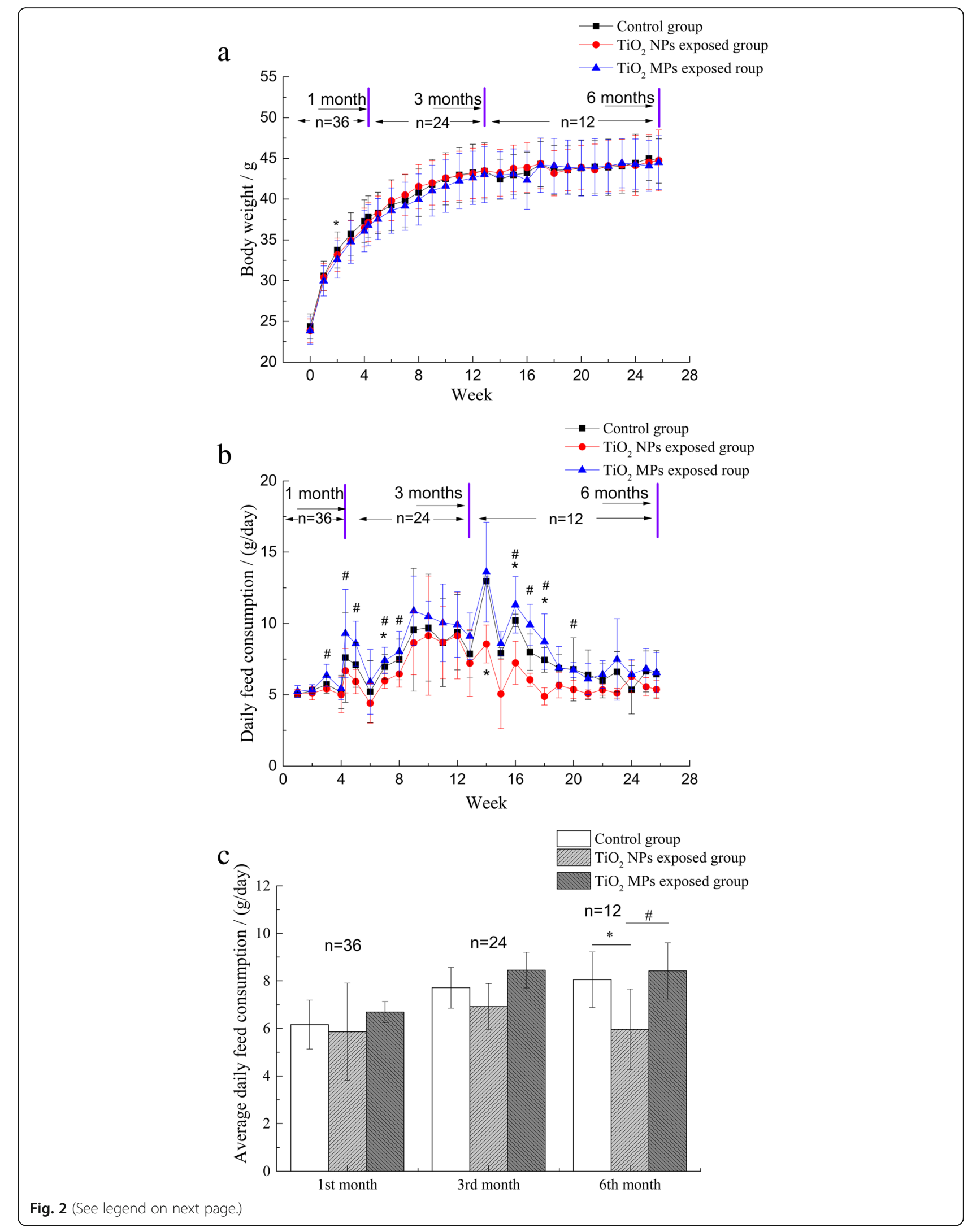


(See figure on previous page.)

Fig. 2 Change of body weight (a) and daily feed intake $(\mathbf{b}, \mathbf{c})$ in mice during exposure to $\mathrm{TiO}_{2} \mathrm{NPs}_{\mathrm{s}}$ or $\mathrm{TiO}_{2} \mathrm{MPs}$-mixed feed for 1,3 , and 6 months (mean $\pm \mathrm{SD}$ ). *: difference between $\mathrm{TiO}_{2} \mathrm{NP}$ exposed group and control group is statistically significant, $p<0.05$; \#: difference between $\mathrm{TiO}_{2} \mathrm{NPS}$ exposed group and $\mathrm{TiO}_{2}$ MPs exposed group is statistically significant, $p<0.05$. n: number of mice per group in each period, as 4 mice were housed in one cage, $\mathrm{n} / 4$ data points (one data per cage) were included for sensitivity analysis

the 3rd and the 6th month (Fig. 5). LPS stimulation didn't cause any noticeable changes as well.

We also assessed the villi height/crypt depth ratio in different segments of the small intestine (Table 4). Compared with the control group, in the duodenum, the villi height/crypt depth ratio increased significantly after 1month exposure to $\mathrm{TiO}_{2} \mathrm{NPs}$ or $\mathrm{TiO}_{2}$ MPs as well as after LPS stimulation by the end of the 1st month, but the ratio decreased after LPS stimulation by the 3rd and the 6th month. In the jejunum, the villi height/crypt depth ratio increased after 1- and 3-month exposure to $\mathrm{TiO}_{2}$ MPs or $\left(\mathrm{TiO}_{2} \mathrm{NPs}+\mathrm{LPS}\right)$. In the ileum, the villi height/crypt depth ratio decreased after 1-month exposure to $\mathrm{TiO}_{2} \mathrm{NPs},\left(\mathrm{TiO}_{2} \mathrm{MPs}+\right.$ LPS $)$ and after LPS stimulation by the 1 st month, but the ratio increased after 3-month exposure to $\mathrm{TiO}_{2} \mathrm{NPs}$ or $\mathrm{TiO}_{2}$ MPs. In further interaction analysis (Table 3 ), we observed antagonistic interactions in villi height/crypt depth ratio between $\mathrm{TiO}_{2}$ NPs and LPS in the duodenum after 1month exposure, in the jejunum after 3-months exposure, and in the ileum after 1-month and 3-months exposure. The interactions between $\mathrm{TiO}_{2}$ MPs and LPS over the villi height/crypt depth ratio in duodenum and jejunum were antagonistic effect after 1-month exposure but synergistic effect after 3-months exposure.

Collectively, exposure of $\mathrm{TiO}_{2} \mathrm{NPs}$ and $\mathrm{TiO}_{2}$ MPs mostly increased the villi height/crypt depth ratio in the small intestine, but LPS stimulation mainly reduced the villi height/crypt depth ratio. Although increased jejunal villi height/crypt depth ratio presented in $\left(\mathrm{TiO}_{2} \mathrm{NPs}+\right.$ LPS) group, an antagonistic interaction was found between $\mathrm{TiO}_{2}$ NPs and LPS. Ileal villi height/crypt ratios decreased in $\left(\mathrm{TiO}_{2} \mathrm{MPs}+\mathrm{LPS}\right)$ group, the interaction between $\mathrm{TiO}_{2}$ MPs and LPS were antagonistic after 1month exposure and synergistic after 3-month exposure. It should be noted that these effects on villi height/crypt depth ratios of the small intestine disappeared when the $\mathrm{TiO}_{2}$ exposure lasted for 6 months.

\section{Intestinal epithelial ultrastructure and expression of tight junction proteins}

Among the 6-months-fed groups, the ultrastructures of ileal epithelial of control group, $\mathrm{TiO}_{2} \mathrm{NPs}$ exposed group and $\mathrm{TiO}_{2}$ MPs exposed group were assessed (Fig. $3 b)$. Some spherical shaped particles with diameter of $(48.5 \pm 13.9) \mathrm{nm}$ and $(84.9 \pm 16.0) \mathrm{nm}$ were observed in the epithelial cell cytoplasm in $\mathrm{TiO}_{2} \mathrm{NPs}$ and $\mathrm{TiO}_{2} \mathrm{MPs}$ exposed groups respectively (Fig. $3 \mathrm{~b}$ ), which parallel the shape and size of $\mathrm{TiO}_{2} \mathrm{NPs}$ and $\mathrm{TiO}_{2}$ MPs being used in this study therefore it's high likely that these observed particles are $\mathrm{TiO}_{2}$ particles. Comparing to control group, height and density of microvilli were reduced in $\mathrm{TiO}_{2}$ MPs exposed group while not in $\mathrm{TiO}_{2} \mathrm{NPs}$ exposed group. No other ultrastructural changes were observed in both $\mathrm{TiO}_{2}$ exposed group.

We examined expression of tight junction proteins in ileal epithelial. As indicated in Fig. 6, 1-month exposure to $\mathrm{TiO}_{2}$ NPs notably increased occludin expression. Exposure to $\mathrm{TiO}_{2} \mathrm{MPs},\left(\mathrm{TiO}_{2} \mathrm{NPs}+\mathrm{LPS}\right)$ and $\left(\mathrm{TiO}_{2} \mathrm{MPs}\right.$ + LPS) upregulated expression of ZO-1 at the 1st month, and $\left(\mathrm{TiO}_{2} \mathrm{MPs}+\mathrm{LPS}\right)$ exposure continued to upregulate ileal ZO-1 level significantly at the 6th month. We observed an antagonistic effect between $\mathrm{TiO}_{2}$ NPs and LPS over the expression of ileal occludin by the 1st month, however, such interaction disappeared by the 3rd and 6th month (Table 3 ).

\section{Inflammatory biomarker in ileum and serum}

In ileum tissues, levels of IL-1 $\beta$, IL-6, IL-10, IL-13, TNF$\alpha$ and IFN- $\gamma$ in both $\mathrm{TiO}_{2} \mathrm{NPs}$ and $\mathrm{TiO}_{2}$ MPs exposed groups remained similar as control group (Fig. 7 A1A18). After stimulation with LPS, ileal IL-1 $\beta$ levels in LPS group and $\left(\mathrm{TiO}_{2} \mathrm{NPs}+\right.$ LPS $)$ exposed group at the 1st month were significantly lower than in control group, while no difference was observed between LPS and $\left(\mathrm{TiO}_{2} \mathrm{NPs}+\right.$ LPS $)$ group. We didn't observe any interaction between both $\mathrm{TiO}_{2}$ and LPS over these ileal cytokine levels (Table 3).

Serum inflammatory biomarkers were also not seen change notably (Fig. 7 B1-B18). Comparing to control group, serum IL-1 $\beta$ level was significantly lower in $\mathrm{TiO}_{2}$ MPs exposed group at the 3rd month and in $\mathrm{TiO}_{2} \mathrm{NPs}$ exposed group at the 6th month, serum IL-6 level in $\mathrm{TiO}_{2}$ MPs exposed group notably dropped at the 6th month. After stimulation with LPS, LPS group displayed higher serum TNF- $\alpha$ levels than control group at the 6th month, but the cytokine levels of $\left(\mathrm{TiO}_{2} \mathrm{NPs}+\mathrm{LPS}\right)$ and $\left(\mathrm{TiO}_{2}\right.$ MPs + LPS) groups were still similar to control group at all time points. By the 6th month, we observed an antagonistic interaction of $\mathrm{TiO}_{2} \mathrm{NPs}$ and LPS over serum IL-1 $\beta$ levels (Table 3).

\section{Discussion}

The highlights of this study are that $\mathrm{TiO}_{2}$ was mixed into feed and fed to mice for up to 6 months for exposure. Such exposure method was subtle and avoided any 


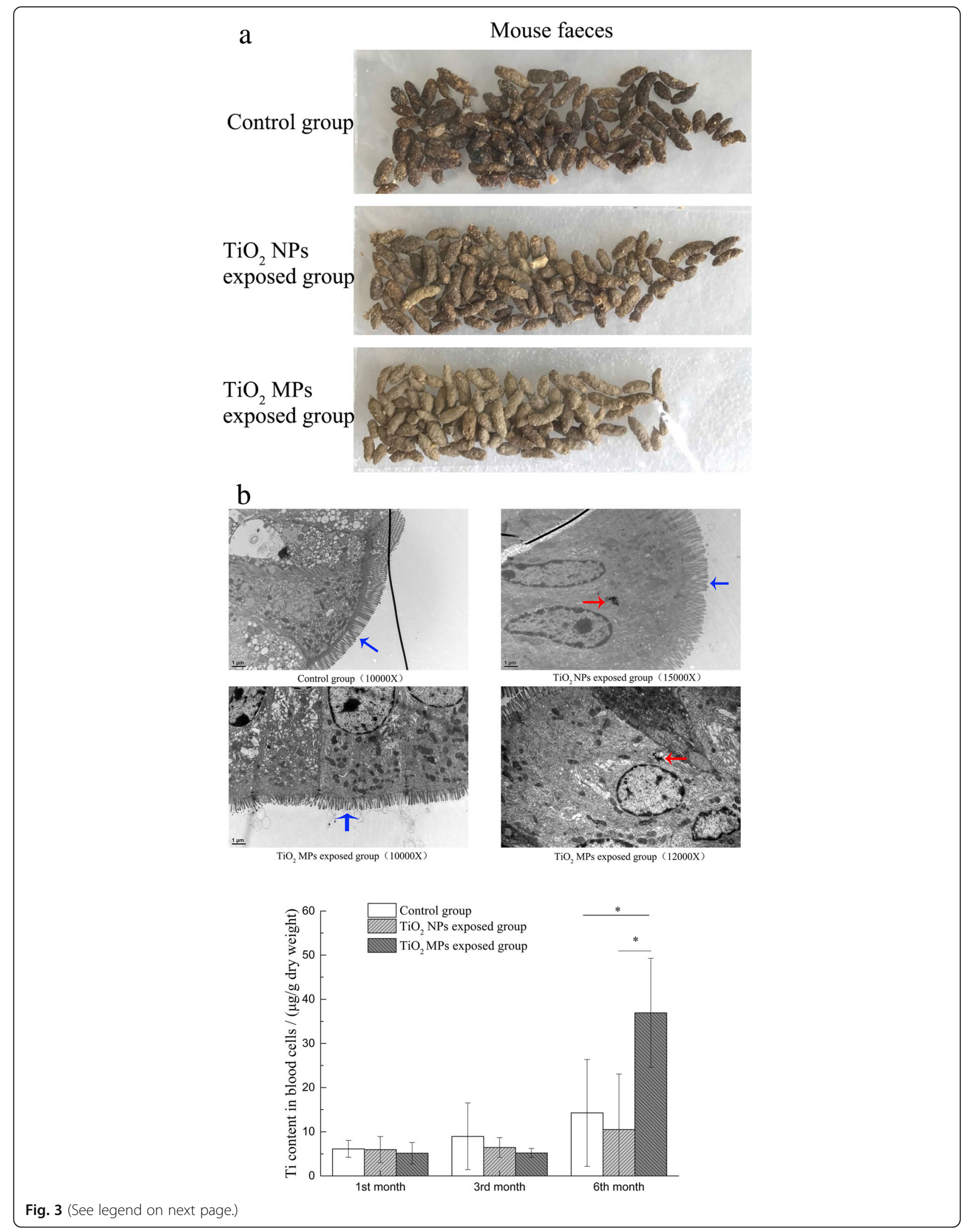


(See figure on previous page.)

Fig. 3 The translocation of $\mathrm{TiO}_{2}$ particles from the gastrointestinal tract. (a) Fecal images of mice fed with control feed, $1 \%(\mathrm{~W} / \mathrm{W}) \mathrm{TiO} 2 \mathrm{NPs}$ or $\mathrm{TiO}_{2}$ MPs mixed feed for 21 days of exposure. Similar feces were observed from day 21 onwards (from day 21 to the end of exposure). (b) TEM images of ileum mucosa in mice after fed with $\mathrm{TiO}_{2} \mathrm{NPs}_{\text {or }} \mathrm{TiO}_{2} \mathrm{MPs}$-mixed feed for 6 months. Red arrows indicate $\mathrm{TiO}_{2}$ particles internalized into intracellular vesicles. Blue arrows indicate microvilli. (c) Ti content in mice blood cells ( $\mu \mathrm{g} / \mathrm{g}$ dry weight) after feeding with control, $1 \%(\mathrm{w} / \mathrm{w}) \mathrm{TiO} \mathrm{O}_{2}$ NPs or $1 \%(\mathrm{w} / \mathrm{W}) \mathrm{TiO}_{2}$ MPs-mixed feed (mean $\left.\pm \mathrm{SD}, \mathrm{n}=5\right)$ for up to $1,3,6$ months

potential stimuli associated with oral gavage that has been used in most in vivo studies. In the meanwhile, the exposure method is more comparable to actual exposure that human experiences, where $\mathrm{TiO}_{2}$ particles are often been ingested along with food. Moreover, rodents are nocturnal and most activities happens during the night, including feeding, our exposure method guaranteed the $\mathrm{TiO}_{2}$ were ingested via daily activities, other exposure methods like oral gavage which often happens during the daytime fail to capture this. Hence, the research is valuable for evaluating the safety of food additive $\mathrm{TiO}_{2}$. Moreover, this is the first study to extend in vivo exposure of $\mathrm{TiO}_{2}$ particles to 6 months and reveal the minor biological impacts of $\mathrm{TiO}_{2}$ following chronic exposure by studying its translocation from intestine, impacting on intestinal barrier, pro-inflammation potency and its potential to interact with LPS in gut.

\section{Translocation of $\mathrm{TiO}_{2} \mathrm{NPs}$ and $\mathrm{TiO}_{2}$ MPs from gut and animal behavior}

In this study, ingesting $\mathrm{TiO}_{2}$ NPs-mixed or $\mathrm{TiO}_{2}$ MPs-mixed feed for 6 months did not influence body weight of the mice, but $\mathrm{TiO}_{2}$ NPs exposure notably decreased the feed intake. The possible explanation is that the exposure time is not long enough for the decreased feed intake influence body weight or the physical activity of mice were reduced after $\mathrm{TiO}_{2}$ exposure. It's a pity were cannot verify as we have no activity data available. The low feed intake might lead to malnutrition and increased health risks in the long run, and more attention should be paid to its longterm impact on nutrition imbalance in further studies. Our previous study identified $\mathrm{TiO}_{2}$ NPs of small sizes could affect nutrient absorption and metabolism by inducing intestinal epithelial injury, with amino acids more susceptible than metal elements and glucose [37]. However, after 6-months of exposure to $\mathrm{TiO}_{2}$ in this study, no notable histopathological changes were found in the small intestine of mice, including the intestinal villi height/crypt depth ratio. It seems the intestinal nutrient absorption wasn't increased by $\mathrm{TiO}_{2}$ NPs exposure. Hence, the low feed intake of $\mathrm{TiO}_{2}$ NPs exposed group might result in energy and nutrient deficiency, leading to malnutrition and other diseases. More researches are still needed for verification in the future.
As frequently reported, $\mathrm{TiO}_{2}$ particles had a very low bioavailability in both in vitro and in vivo studies [16, 18, 38, 39]. In both $\mathrm{TiO}_{2}$ NPs exposed group and $\mathrm{TiO}_{2}$ MPs exposed group, the Ti contents in blood cells were found to be low and are of similar concentration as control group, except for the increased Ti content at the 6th month in $\mathrm{TiO}_{2}$ MPs exposed group. And the Ti content also didn't increased significantly in liver, kidney and spleen [40]. These results suggest the bioavailability of $\mathrm{TiO}_{2}$ was low and most of the $\mathrm{TiO}_{2}$ particles might be excreted with feces, which are in accordance with the excretion of white feces we observed. $\mathrm{TiO}_{2}$ particles were white pigment and the feces were easily whitened by these $\mathrm{TiO}_{2}$ particles when they are excreted with feces.

It's well known that the particles with smaller size could be transported through the biological barriers easier than these with larger sizes, hence the low bioavailability could be partially explained by the agglomeration of $\mathrm{TiO}_{2}$ particles in the gastrointestinal tract as shown in Table 1. Once being ingested, $\mathrm{TiO}_{2}$ particles will move through various digestive juices, including saliva, gastric and intestinal juices. The local biomolecules within these digestive juices, feed components as well as intestinal flora products like LPS may coat onto the surface of $\mathrm{TiO}_{2}$ particles and form protein corona, which may substantially change physiochemical properties of $\mathrm{TiO}_{2}$ particles and influence its bioavailability [41, 42]. Sinnecker [43] also reported that luminal gut-constituents may both attenuate and augment the adherence of nanoparticles to cell surface, the process of which is particle sizedependent and interacting biomolecular dependent. In addition, as reported in a recent research [44], the limited $\mathrm{Ti}$ translocation could also be explained by the presence of intestinal mucus which can trap food-grade $\mathrm{TiO}_{2}$ particles.

\section{Effect of $\mathrm{TiO}_{2} \mathrm{NPs}$ and $\mathrm{TiO}_{2} \mathrm{MPs}$ on intestinal barrier function}

Intestinal barrier function mainly relies on the integrity of the intestinal epithelial cell barrier, which is composed of intestinal epithelial cells and intercellular tight junctions [15]. Thus, we checked the intestinal epithelial histological structure and ultrastructure, the expression of tight junction proteins and the intestinal permeability in this study. 


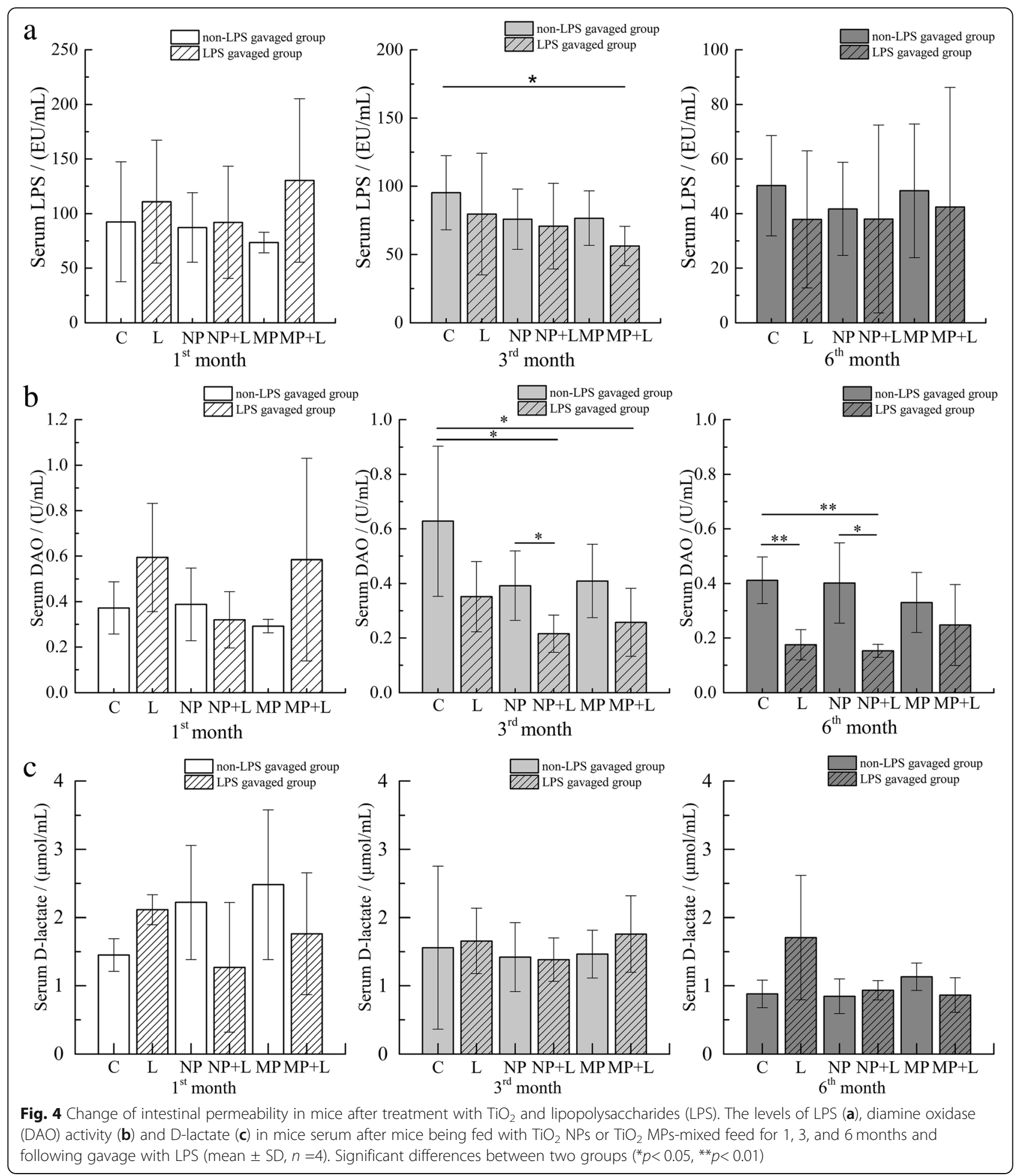

Based on the observations (as summarized in Table 5), both $\mathrm{TiO}_{2}$ increased villi height/crypt depth ratio in the small intestine at the 1 and 3 months without causing histological injuries. Sparse and short microvilli were found in $\mathrm{TiO}_{2}$ MPs exposed group at the 6th months. Studies [45-47] have shown that a decreased villi height/crypt depth ratio or a reduced villi surface area is considered deleterious for digestion and absorption and could result in retarded growth, conversely, an increased villi height-to-crypt depth ratio as well as an increased villi surface area could promote the intestinal digestionabsorption function. The sparse and short microvilli 
Table 1 The dispersion state of $\mathrm{TiO}_{2}$ particles in ultrapure water, artificial gastric/intestinal juice (AGJ/AIJ)

\begin{tabular}{|c|c|c|c|c|c|c|c|c|c|}
\hline \multirow[t]{2}{*}{ Material } & \multicolumn{3}{|l|}{ Ultrapure water } & \multicolumn{3}{|l|}{ AGJ } & \multicolumn{3}{|l|}{ AIJ } \\
\hline & $\begin{array}{l}\text { Hydrodynamic } \\
\text { diameter(nm) }\end{array}$ & PDI & $\begin{array}{l}\text { Zeta- } \\
\text { potential(mV) }\end{array}$ & $\begin{array}{l}\text { Hydrodynamic } \\
\text { diameter(nm) }\end{array}$ & PDI & $\begin{array}{l}\text { Zeta- } \\
\text { potential }(\mathrm{mV})\end{array}$ & $\begin{array}{l}\text { Hydrodynamic } \\
\text { diameter(nm) }\end{array}$ & PDI & $\begin{array}{l}\text { Zeta- } \\
\text { potential }(\mathrm{mV})\end{array}$ \\
\hline $\mathrm{TiO}_{2} \mathrm{NPS}^{\mathrm{a}}$ & $942.6 \pm 319.8$ & $\begin{array}{l}0.90 \pm \\
0.11\end{array}$ & $-18.37 \pm 1.04$ & $1350 \pm 248.95$ & $\begin{array}{l}0.99 \pm \\
0.02\end{array}$ & $2.37 \pm 0.92$ & $805.3 \pm 265.0$ & $\begin{array}{l}0.83 \pm \\
0.17\end{array}$ & $-23.67 \pm 1.68$ \\
\hline $\mathrm{TiO}_{2} \mathrm{MPs}^{\mathrm{a}}$ & $1071.9 \pm 128.7$ & $\begin{array}{l}0.95 \pm \\
0.08\end{array}$ & $-15.37 \pm 0.35$ & $1497 \pm 366.38$ & $\begin{array}{l}1.00 \pm \\
0.00\end{array}$ & $2.15 \pm 0.99$ & $1194.3 \pm 183.6$ & $\begin{array}{l}0.99 \pm \\
0.02\end{array}$ & $-13.53 \pm 0.45$ \\
\hline $\begin{array}{l}\mathrm{TiO}_{2} \mathrm{NPs} \text {-mixed } \\
\text { feed }\end{array}$ & NT & NT & NT & $1560.7 \pm 561.9^{b}$ & $\begin{array}{l}0.97 \pm \\
0.05^{\mathrm{b}}\end{array}$ & $-3.17 \pm 0.26^{b}$ & $348.2 \pm 54.8^{c}$ & $\begin{array}{l}0.47 \pm \\
0.10^{c}\end{array}$ & $-6.48 \pm 1.34^{c}$ \\
\hline $\begin{array}{l}\mathrm{TiO}_{2} \text { MPs-mixed } \\
\text { feed }\end{array}$ & NT & NT & NT & $1636.4 \pm 722.8^{b}$ & $\begin{array}{l}0.97 \pm \\
0.09^{b}\end{array}$ & $-0.92 \pm 1.22^{\mathrm{b}}$ & $670.3 \pm 286.0^{c}$ & $\begin{array}{l}0.79 \pm \\
0.18^{c}\end{array}$ & $-13.03 \pm 2.03^{c}$ \\
\hline
\end{tabular}

Notes. a: Hydrodynamic diameters, PDI and zeta potential of $\mathrm{TiO}_{2}$ particles after being suspended in ultrapure water, AGJ or AIJ (the final test concentration is 0.5 $\mathrm{mg} / \mathrm{mL}$ ) respectively. b: Hydrodynamic diameters, PDI and zeta potential of particles was tested after $\mathrm{TiO}_{2} \mathrm{NPs}_{\mathrm{s}}$ or TiO 2 MPs-mixed feed being digested in AGJ for $2 \mathrm{~h}$ (The final test dose is $0.25 \mathrm{mg} / \mathrm{mL} \mathrm{TiO}_{2}$ ). c: Hydrodynamic diameters, PDI and zeta potential of particles was tested after TiO $\mathrm{NPs}_{2}$ or TiO $\mathrm{MPs}_{2} \mathrm{mixed} \mathrm{feed}$ being digested in AGJ for $2 \mathrm{~h}$ followed by further digestion in AIJ for $2.5 \mathrm{~h}$ (The final test dose is $0.125 \mathrm{mg} / \mathrm{mL} \mathrm{TiO}_{2}$ ). NT:no test; PDI: polydispersity index

would reduce the villi surface area and result in decreased intestinal digestive and absorptive capacity. As microvilli structure remain unaffected in $\mathrm{TiO}_{2} \mathrm{NPs}$ exposed group, it may indicate that $\mathrm{TiO}_{2} \mathrm{NPs}$ increased intestinal digestion and absorption area by increasing villi height/crypt ratio, which may help explain the reduced feed consumption as discussed above. Similar results were reported by Ammendolia et al [48] where $\mathrm{TiO}_{2}$ NPs increased jejunal villi height/crypt ratio without damaging intestinal mucosa epithelium. In $\mathrm{TiO}_{2} \mathrm{MPs}$ exposed group, though increased villi height/crypt depth ratios were observed at the 1 and 3 months, severely reduced microvilli height and density in intestinal columnar epithelium were observed at the 6 months. It suggested long time exposure to $\mathrm{TiO}_{2} \mathrm{MPs}$ would cause intestinal injury, which would contribute to the increased Ti content in blood cells after 6 months exposure to $\mathrm{TiO}_{2}$ MPs since more particles would translocate through the damaged intestinal epithelial. Moreover, there is one study [49] showed that exposure to foodgrade $\mathrm{TiO}_{2}$ (E171) for 100 days in rats triggered lowgrade inflammation and initiated preneoplastic lesions in colon featuring increased number of aberrant crypts, and increased number of large aberrant crypt foci at the colonic mucosal surface. Although it remains unclear whether the increased villi height/crypt depth ratio we observe might also associate with the health risks of intestinal villus hyperplasia and carcinogenesis, more attention should be paid to the long-term effects of $\mathrm{TiO}_{2}$ exposure along with these changes.

Tight junction plays an important role in maintaining the integrity of intestinal epithelial barrier and intestinal permeability. A recent in vitro study [50] reported that $\mathrm{TiO}_{2}$ NPs upregulated ZO- 1 , occludin and claudin- 2 expression in a shape- and time-dependent manner in an in vitro model (Caco-2/HT29) of the intestinal barrier. In the current study, increased $\mathrm{ZO}-1$ and occludin are only observed in the 1st month, which make it difficult for us to conclude our results parallel the in vitro findings, such uncertainly is further supported by the absence of reduced intestinal permeability (no notable changes in serum DAO activity, LPS and D-lactate levels suggest no notable change of intestinal permeability) since upregulated tight junction protein would lead to decreased intestinal permeability. It is also inconsistent with our earlier research [22] where we observed declined serum DAO activity and D-lactate content after continuous gavage of $200 \mathrm{mg} / \mathrm{kg} \mathrm{TiO}_{2}$ NPs (TEM measured size: $75 \pm 15 \mathrm{~nm}$; BET specific surface area: 63.95 $\mathrm{m}^{2} / \mathrm{g}$ ) to adult SD rats for 30 days, which indicates decreased intestinal mucosal permeability. These differences may originate from the differences in animal species, exposure methods, exposure time length and the physiochemical properties of the $\mathrm{TiO}_{2}$ particles used.

\section{Inflammatory response induced by $\mathrm{TiO}_{2} \mathrm{NPs}$ and $\mathrm{TiO}_{2}$ MPs}

The intestinal immunity is an important part of systemic immunity and regulates the function of intestinal epithelial tight junction. In the present study, we analyzed five proinflammatory cytokines (IL-1 $\beta$, IL-6, IL-13, TNF- $\alpha$, and IFN- $\gamma$ ) and one anti-inflammatory cytokine (IL-10). Briefly, IL- $1 \beta$, TNF- $\alpha$, IFN- $\gamma$ can impact on MLCK and eventually increase tight junction permeability. IL- 6 is capable of inducing immune cell differentiation and plays a proinflammatory role which includes promoting $\mathrm{T}$ cells to differentiate into Th17 cells. IL-17, secreted by Th17 cells, and IL-13 can both upregulate claudin-2 concentration, which in turn increases intercellular pore channel permeability, thus increasing the permeability of the intestinal barrier. Anti-inflammatory cytokine IL-10 however inhibits the differentiation of Th1 cells, enabling it to play an anti-inflammatory role in the intestinal tract, thereby maintaining the homeostasis of barrier permeability. 


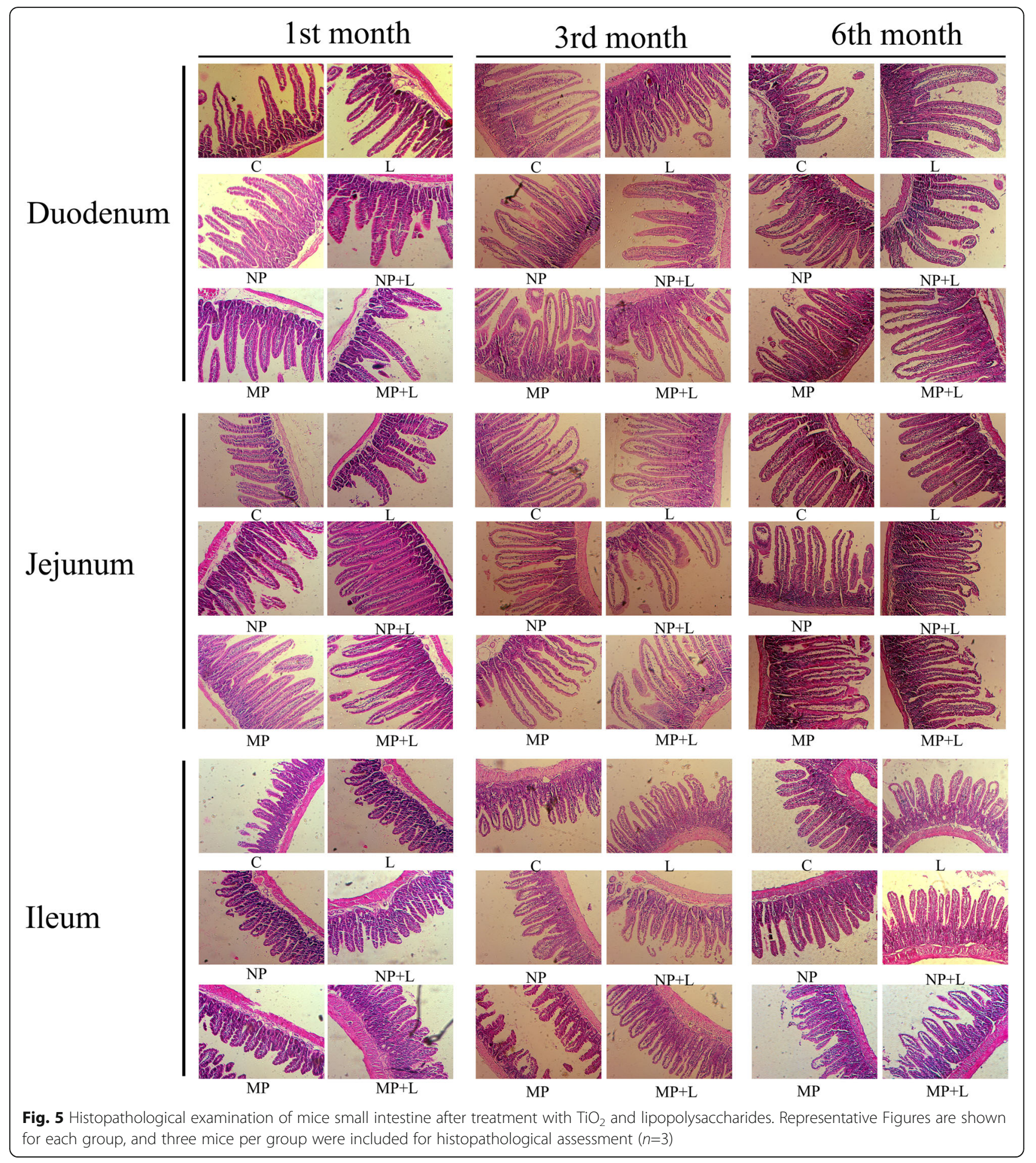

Exposure to $\mathrm{TiO}_{2} \mathrm{NPs}$ or $\mathrm{TiO}_{2} \mathrm{MPs}$ for up to $1,3,6$ months has not increased serum nor ileal cytokine levels, suggesting that $\mathrm{TiO}_{2} \mathrm{NPs}$ or $\mathrm{TiO}_{2} \mathrm{MPs}$ exposure did not cause notable inflammation. Nogueira et al [23] tested the potential of $\mathrm{TiO}_{2}$ to induce intestinal inflammation in Bl57/6 mice, they found that $\mathrm{TiO}_{2}$ NPs can increase cytokine IL - 4, IL - 12, IL - 23, TNF- $\alpha$, IFN- $\gamma$, TGF- $\beta$ levels in duodenum, jejunum and ileum, of which the ileum showed the highest level of cytokine. These different observations might be explained from several aspects. First, we used different $\mathrm{TiO}_{2}$ particles, the differences in physiochemical properties may result in different affinity to biomolecules and feed components, which may lead to different surface coating of these particle and different 


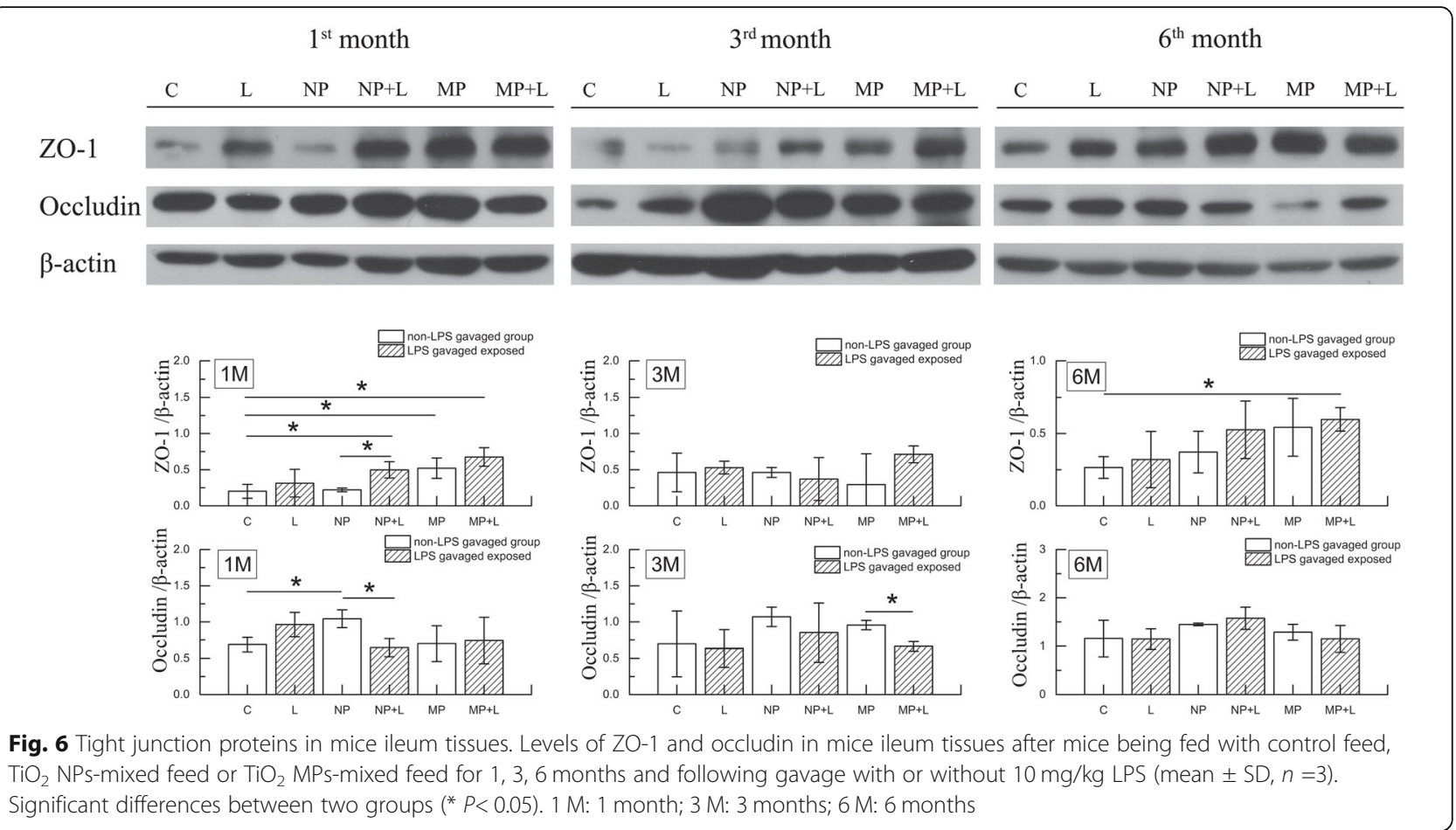

biological effects. Second, the mild reactions found in this study might attribute to the exposure method we used which avoided addition stress accompanied by gavage, and won't lead to intensive $\mathrm{TiO}_{2}$ exposure in just seconds. Third, the dosage and the length of exposure were different. Last, the animal model we used in current study, the outbred ICR mice, is less sensitive to subtle stimuli, which is also an important reason for the different observations.

\section{Combined effect of TiO2 NPs and TiO2 MPs with LPS}

After LPS stimulation, we observed increased expression of tight junction protein ZO-1 and declined serum DAO activity in $\left(\mathrm{TiO}_{2} \mathrm{NPs}+\right.$ LPS $)$ exposed group and $\left(\mathrm{TiO}_{2}\right.$ MPs + LPS) exposed group when compared to the $\mathrm{TiO}_{2}$ NPs exposed group and $\mathrm{TiO}_{2}$ MPs exposed group respectively, implying that co-exposure of $\mathrm{TiO}_{2}$ and LPS reduced the permeability of the intestinal barrier. The intestinal villi height/crypt depth ratio was also found after co-exposure of $\mathrm{TiP}_{2}$ and LPS. However, cytokines were not seen notably increased in $\left(\mathrm{TiO}_{2} \mathrm{NPs}+\right.$ LPS $)$ and $\left(\mathrm{TiO}_{2}+\mathrm{LPS}\right)$ treatment groups. The antagonistic effects were mostly found between $\mathrm{TiO}_{2}$ NPs and LPS.

The interaction between $\mathrm{TiO}_{2}$ and LPS have been reported in several studies. Riedle $\mathrm{S}$ et al [51] reported that the cell viability of bone marrow-derived macrophages was unaffected when $\mathrm{TiO}_{2}$ particles were applied after LPS exposure, but $\mathrm{TiO}_{2}$ particles could augmented LPS induced inflammation, Bianchi et al [52] found that compared to sole-exposure of LPS or $\mathrm{TiO}_{2}$ NPs, strengthened and more persistent inflammation in RAW264.7 cells were observed when LPS adsorbed onto nano- $\mathrm{TiO}_{2}$ protein corona. It is clear that these in vitro studies indicated synergistic effects between $\mathrm{TiO}_{2}$ NPs and LPS. Our recent work [53] found that $\mathrm{TiO}_{2}$ NPs could modify gut microbiota community structure and mitigate TNBS induced colitis. These contradictory findings may be well caused by the differences between in vitro and in vivo system, the different findings may also lie in the differences between physiochemical properties of $\mathrm{TiO}_{2}$ particle as well as the differences in dosage. In addition, $\mathrm{TiO}_{2} \mathrm{NPs}$ are usually applied together with LPS in in vitro studies, while in the current study, mice were fasted for $6 \mathrm{~h}$ before LPS administration, and as mice is nocturnal rodent, LPS was administered during the non-active phase of the mice. For more clarity, more researches are still needed.

\section{Conclusion}

This study found that short-term and long-term ingesting $\mathrm{TiO}_{2} \mathrm{NPs}$ and $\mathrm{TiO}_{2}$ MPs-mixed feed would alter intestinal villi structure without impairing intestinal barrier function, however, co-exposure of $\mathrm{TiO}_{2} \mathrm{NPs}$ or $\mathrm{TiO}_{2} \quad$ MPs and LPs would enhance intestinal barrier function without causing notable inflammatory responses. In addition, $\mathrm{TiO}_{2} \mathrm{NPs}$ showed antagonistic effect with LPS over intestinal villi height/crypt depth ratio. The gentle exposure method (i.e. feeding $\mathrm{TiO}_{2}$ mixed feeds) might have contributed to the mild chronic biological effects of $\mathrm{TiO}_{2} \mathrm{NPs}$ observed in the current study. Since ingested $\mathrm{TiO}_{2}$ via mixed feed and via oral gavage could present different physiochemical properties 


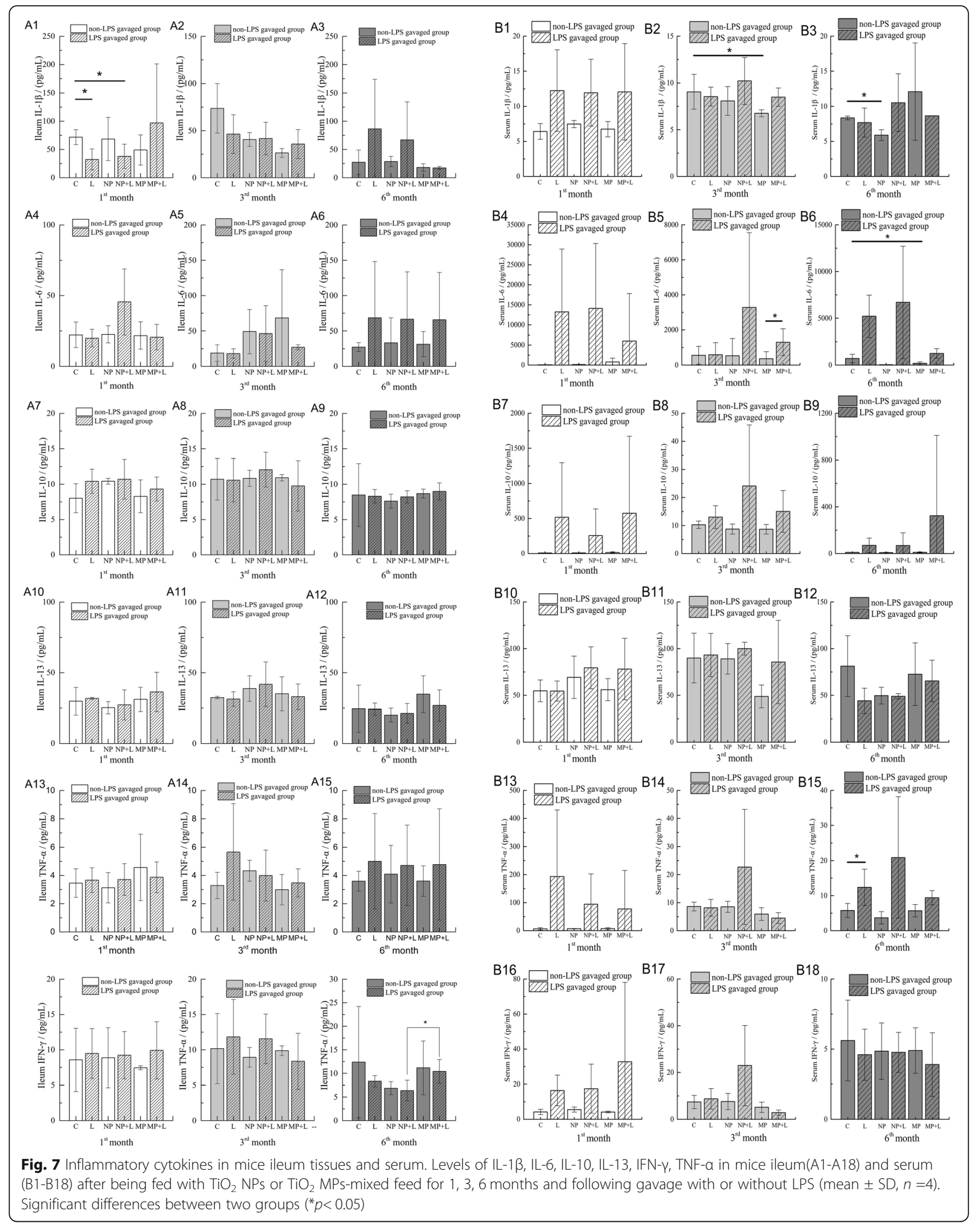


Table 2 Animal grouping and treatment

\begin{tabular}{|c|c|}
\hline Group & Treatment \\
\hline C & Feed with normal feed for $1,3,6$ months \\
\hline NP & Feed with $\mathrm{TiO}_{2} \mathrm{NPs}$-mixed feed for $1,3,6$ months \\
\hline MP & Feed with $\mathrm{TiO}_{2}$ MPs-mixed feed for 1, 3, 6 months \\
\hline L & ig $10 \mathrm{mg} / \mathrm{kg}$ LPS after feeding with the normal feed for $1,3,6$ months \\
\hline$N P+L$ & ig $10 \mathrm{mg} / \mathrm{kg}$ LPS after feeding with the $\mathrm{TiO}_{2}$ NPs-mixed feed for $1,3,6$ months \\
\hline$M P+L$ & ig $10 \mathrm{mg} / \mathrm{kg}$ LPS after feeding with the $\mathrm{TiO}_{2}$ MPs-mixed feed for $1,3,6$ months \\
\hline
\end{tabular}

Note: ig, intragastric administration

in gastrointestinal tract which would in turn result in different biological effects, and as ingesting $\mathrm{TiO}_{2}$ with feed represents the exposure route of human being, the current research is very valuable for evaluating the safety of food additive $\mathrm{TiO}_{2}$ and more attention should be paid to exploring the biological effects of $\mathrm{TiO}_{2} \mathrm{NPs}$ under realistic exposure conditions. Considering that $\mathrm{TiO}_{2}$ is a suspected carcinogen and might associate with the increased risk for the formation of colonic carcinoma, more researches are needed for clarifying whether the histological changes of intestinal villi and crypts associate with hyperplasia and carcinogenesis or not. In addition, there is a large number of bacteria exist in the intestine, among which Gram-negative bacteria produce LPS, the continuous effect of the combined exposure of $\mathrm{TiO}_{2}$ and LPS should attract attention.

\section{Methods}

\section{Physiochemical characterization of $\mathrm{TiO}_{2}$ particles}

Two food-grade $\mathrm{TiO}_{2}$ particles were purchased from Shanghai Yunfu Nanotechnology Co. Ltd., China. The primary size and shape of both $\mathrm{TiO}_{2}$ particles were determined using a transmission electron microscopy (TEM, JEM-2100F, JEOL, Japan). The crystal structures of both $\mathrm{TiO}_{2}$ were assessed with an X-ray powder diffractometry (XRD, X'Pert Pro, PANalytical). The specific surface areas were assessed based on Brunauer-Emmett-Teller (BET) method (Autosorb-iQ2-MP, Malvern Panalytical). The purity and impurities were analyzed with an inductively coupled plasma mass spectrometry (ICP-MS, Thermo Elemental X7, Thermo Electron Corporation).

Artificial gastric juice (AGJ) and artificial intestinal juice (AIJ) were prepared as described in our earlier study [22]. Briefly, the AGJ $(\mathrm{pH}=1.2)$ was prepared with $10 \mathrm{~g} / \mathrm{L}$ pepsin (3800 units/mg) and $45 \mathrm{mmol} / \mathrm{L} \mathrm{HCl}$. The AIJ ( $\mathrm{pH}=6.8)$ was constituted by $10 \mathrm{~g} / \mathrm{L}$ trypsin and 6.8 $\mathrm{g} / \mathrm{L} \mathrm{KH}_{2} \mathrm{PO}_{4}$. Both $\mathrm{TiO}_{2}$ particles were suspended in ultrapure water, AGJ or AIJ respectively and were ultrasonicated for $30 \mathrm{~min}$ before measuring its hydrodynamic diameter, polydispersity index values (PDI) and Zetapotential using a ZetaSizer Nano ZS90 (Malvern Instruments Ltd., Malvern, UK).

\section{Feed preparation and characterization}

The commercial pellet diet and two kinds of $\mathrm{TiO}_{2}$-mixed feeds were supplied by Beijing Ke Ao Xie Li Food Co. Ltd., China. The $\mathrm{TiO}_{2}$-mixed feeds were produced by mixing $1 \%$ (mass fraction) $\mathrm{TiO}_{2} \mathrm{NPs}$ or $\mathrm{TiO}_{2}$ MPs into the commercial pellet diet. This dosage was selected based on the maximum usage of $\mathrm{TiO}_{2}$ allowed in food, where both the U.S. Food \& Drug Administration and the national food safety criteria of China (GB 27602014) have regulated $\mathrm{TiO}_{2}$ usage in food should be no more than $1 \%$ of the total weight.

$\mathrm{TiO}_{2} \mathrm{NPs}$ or $\mathrm{TiO}_{2}$ MPs-mixed feed was digested in AGJ for $2 \mathrm{~h}$ firstly, and then moved into AIJ for further digestion of $2.5 \mathrm{~h}$. The above experiment was conducted on a horizontal shaker to mimic feed digestion in vivo. After digestion, the suspensions were collected and

Table 3 The interaction between $\mathrm{TiO}_{2}$ particles and LPS on mice

\begin{tabular}{|c|c|c|c|c|c|c|c|c|c|c|c|}
\hline \multirow{3}{*}{$\begin{array}{l}\text { Interaction } \\
\text { between }\end{array}$} & \multirow{3}{*}{$\begin{array}{l}\text { Exposure } \\
\text { Time of } \\
\mathrm{TiO}_{2}\end{array}$} & \multicolumn{10}{|c|}{ Parameters of } \\
\hline & & \multicolumn{3}{|c|}{ Intestinal permeability } & \multicolumn{2}{|c|}{ Tight junction proteins } & \multicolumn{3}{|c|}{ Villi height/crypt depth ratio } & \multicolumn{2}{|c|}{ Inflammatory biomarkers } \\
\hline & & DAO & LPS & D-lactate & ZO-1 & Occludin & Duodenum & Jejunum & Ileum & Serum & Ileum \\
\hline \multirow[t]{3}{*}{$\mathrm{TiO}_{2} \mathrm{NPs}$ and LPS } & 1 month & - & - & - & - & Ant. & Ant. & - & Ant. & IL-1 $\beta$ (Ant.) & - \\
\hline & 3 months & - & - & - & - & - & - & Ant. & Ant. & - & - \\
\hline & 6 months & - & - & - & - & - & - & - & - & - & - \\
\hline \multirow[t]{3}{*}{$\mathrm{TiO}_{2}$ MPs and LPS } & 1 month & - & - & - & - & - & Ant. & Ant. & - & - & - \\
\hline & 3 months & - & - & - & - & - & Syn. & Syn. & - & - & - \\
\hline & 6 months & Ant. & - & - & - & - & - & - & - & - & - \\
\hline
\end{tabular}

Note: $2^{*} 2$ factorial design analysis. “-“, no interaction effects, $p>0.05$. Syn.: synergistic effect $(p<0.05)$, Ant.: antagonistic effect $(p<0.05)$ 
Table 4 Villi height/ crypt depth ratio in the small intestine after treatment with TiO2 and LPS

\begin{tabular}{|c|c|c|c|c|c|c|c|c|c|}
\hline \multirow[b]{2}{*}{ Group } & \multicolumn{3}{|c|}{ Duodenum villi height/ crypt depth ratio } & \multicolumn{3}{|c|}{ Jejunum villi height/ crypt depth ratio } & \multicolumn{3}{|c|}{ Ileum villi height/ crypt depth ratio } \\
\hline & $\begin{array}{l}1 \text { month } \\
(n=15)\end{array}$ & $\begin{array}{l}3 \text { months } \\
(n=5)\end{array}$ & $\begin{array}{l}6 \text { months } \\
(n=5)\end{array}$ & $\begin{array}{l}1 \text { month } \\
(n=15)\end{array}$ & $\begin{array}{l}3 \text { months } \\
(n=5)\end{array}$ & $\begin{array}{l}6 \text { months } \\
(n=5)\end{array}$ & $\begin{array}{l}1 \text { month } \\
(n=15)\end{array}$ & $\begin{array}{l}3 \text { months } \\
(n=5)\end{array}$ & $\begin{array}{l}6 \text { months } \\
(n=15)\end{array}$ \\
\hline $\bar{C}$ & $3.21 \pm 0.56$ & $3.74 \pm 0.79$ & $4.32 \pm 0.45$ & \pm 0.46 & $4 \pm 0.31$ & $4.08 \pm 0.65$ & $1.96 \pm 0.29$ & $1.58 \pm 0.13$ & $1.93 \pm 0.28$ \\
\hline L & $4.45 \pm 0.84^{\mathrm{a}}$ & $1.95 \pm 0.63^{\mathrm{a}}$ & $3.51 \pm 0.49^{\mathrm{a}}$ & $3.98 \pm 0.69$ & $3.25 \pm 0.42$ & $3.15 \pm 0.67$ & $1.67 \pm 0.12^{\mathrm{a}}$ & $1.62 \pm 0.07$ & $1.89 \pm 0.38$ \\
\hline NP & $3.85 \pm 0.70^{\mathrm{a}}$ & $3.99 \pm 0.65$ & $3.89 \pm 1.08$ & $4.10 \pm 0.80$ & $3.61 \pm 0.71$ & $4.01 \pm 0.50$ & $1.65 \pm 0.12^{\mathrm{a}}$ & $2.05 \pm 0.24^{\mathrm{a}}$ & $1.78 \pm 0.14$ \\
\hline$N P+L$ & $3.31 \pm 0.65^{b, c}$ & $2.86 \pm 0.46^{b, c}$ & $3.62 \pm 0.57$ & $5.18 \pm 1.44^{a, b}, c$ & $4.74 \pm 0.96^{a, b}$ & $3.78 \pm 0.24$ & $1.78 \pm 0.21^{\mathrm{c}}$ & $1.77 \pm 0.15$ & $2.03 \pm 0.28$ \\
\hline MP & $4.41 \pm 0.60^{\mathrm{a}, \mathrm{c}}$ & $4.27 \pm 0.31$ & $4.79 \pm 1.04$ & $4.62 \pm 0.7^{a}$ & $5.03 \pm 0.92^{a, c}$ & $4.86 \pm 0.43^{c}$ & $1.69 \pm 0.12$ & $1.79 \pm 1.61^{\mathrm{a}}$ & $2.02 \pm 0.3$ \\
\hline $1 P+L$ & $3.74 \pm 0.85^{\mathrm{b}, \mathrm{e}}$ & $3.72 \pm 0.48^{b, d}$ & $4.28 \pm 1.11$ & $3.69 \pm 0.66^{d, e}$ & $3.63 \pm 0.44^{d, e}$ & $3.93 \pm 0.54^{d}$ & $1.41 \pm 0.14^{a, b}, d, e$ & $1.68 \pm 0.07$ & $1.92 \pm 0.29$ \\
\hline
\end{tabular}

Note: $a, b, c, d, e, f$ represent statistically significant differences when compared to $C, L, N P$, (NP + L) and MP group respectively, $P<0.05$

ultrasonicated for $30 \mathrm{~min}$ to break up aggregates. The particle hydrodynamic diameter, PDI and Zeta-potential were assessed using ZetaSizer Nano ZS90.

\section{Animal treatment}

The healthy male ICR mice of 3-week old were bred and supplied by the Department of Laboratory Animal Science, Peking University Health Science Center. The animals were fed a sterilized commercial pellet diet and deionized water ad libitum, and were housed in plastic cages in a $20 \pm 2{ }^{\circ} \mathrm{C}$ and $50-70 \%$ relative humidity room with a 12:12 h light-dark cycle. The animal experiments were carried out in accordance with the Guiding Principles in the Use of Animals in Toxicology adopted by Society of Toxicology and the European Union Directive 2010/63/EU for animal experiments and received approval from the Peking University Institutional Review Board (LA2019216).

After five days of acclimation, the 108 mice were randomly divided into 18 groups, 6 mice per group. As shown in Table 2, the mice were given normal feed, $\mathrm{TiO}_{2} \mathrm{NPs}$ mixed feed or $\mathrm{TiO}_{2}$ MPs-mixed feed respectively for up to $1,3,6$ months, fasted for $6 \mathrm{~h}$ and followed by intragastric administration (ig) of $10 \mathrm{mg} /(\mathrm{kg}$ body weight) lipopolysaccharides (LPS, E.coli O111:B4, Sigma Aldrich) or same amount of deionized water. Additional LPS administration was performed to stimulate a flora disruption in the intestine and to investigate whether $\mathrm{TiO}_{2}$ exposure would alter the ability of the intestinal barrier to resist LPS invasion. Four hours later, the animals were anesthetized by ether, blood samples were collected from the eye artery by removing the eyeball quickly, the animals were then sacrificed. Sera were harvested by centrifuging blood samples at $3000 \mathrm{rpm}$ for $10 \mathrm{~min}$ at $4{ }^{\circ} \mathrm{C}$ and the blood cells were kept for analyzing titanium (Ti) content. The tissues and organs including the small intestine were excised and stored in $-80^{\circ} \mathrm{C}$. During the whole experiment, four mice were housed together in a same cage, the animal behaviors, symptoms and mortality were recorded daily. The body weights and feed intake were measured weekly, and daily feed intake per mouse for each week was calculated. For calculating feed intake for longer period (like 1, 3, 6 months we reported), the daily feed intake is calculated as cumulative feed intake of the cage within the period being divided by the number of mice in the cage and the number of days of the period. For sensitivity analysis, each cage represents a data point of four mice, therefore, for the 1st month, we have 27 cages available (108 mice),

Table 5 Notable changes of biological parameters in mice after treatment with $\mathrm{TiO}_{2}$ and LPS

\begin{tabular}{|c|c|c|c|}
\hline Group & 1 month & 3 months & 6 months \\
\hline $\mathrm{L}$ & $\begin{array}{l}\text { Duodenal villi height/ crypt depth ratio } \uparrow \\
\text { lleal villi height/ crypt depth ratio } \downarrow \\
\text { lleal IL-1 } 1 \downarrow \downarrow\end{array}$ & Duodenal villi height/ crypt depth ratio $\downarrow$ & $\begin{array}{l}\text { Duodenal villi height/ crypt depth ratio } \downarrow \\
\text { Serum DAO } \downarrow \\
\text { Serum TNF-a } \uparrow\end{array}$ \\
\hline NP & $\begin{array}{l}\text { Duodenal villi height/ crypt depth ratio } \uparrow \\
\text { lleal villi height/ crypt depth ratio } \downarrow \\
\text { lleal Occludin } \uparrow\end{array}$ & lleal villi height/ crypt depth ratio $\uparrow$ & $\begin{array}{l}\text { Food intake } \downarrow \\
\text { Serum IL-1 } \downarrow \downarrow\end{array}$ \\
\hline$N P+L$ & $\begin{array}{l}\text { Jejunal villi height/ crypt depth ratio } \uparrow \\
\text { lleal ZO- } \uparrow \uparrow\end{array}$ & $\begin{array}{l}\text { Jejunal villi height/ crypt depth ratio } \uparrow \\
\text { Serum DAO } \downarrow\end{array}$ & $\begin{array}{l}\text { Serum DAO } \downarrow \\
\text { lleal IL-1 } \beta \downarrow\end{array}$ \\
\hline MP & $\begin{array}{l}\text { Duodenal villi height/ crypt depth ratio } \uparrow \\
\text { Jejunal villi height/ crypt depth ratio } \uparrow \\
\text { lleal ZO- } \uparrow\end{array}$ & $\begin{array}{l}\text { Jejunal villi height/ crypt depth ratio } \uparrow \\
\text { lleal villi height/ crypt depth ratio } \uparrow \\
\text { Serum IL-1 } \downarrow \downarrow\end{array}$ & $\begin{array}{l}\text { lleal microvilli } \downarrow \text {, Blood Ti } \uparrow \\
\text { Serum IL-6 } \downarrow\end{array}$ \\
\hline$M P+L$ & $\begin{array}{l}\text { lleal villi height/ crypt depth ratio } \downarrow \\
\text { lleal ZO- } \uparrow \uparrow\end{array}$ & Serum LPS $\downarrow$, Serum DAO $\downarrow$ & Ileal ZO-1 $\uparrow$ \\
\hline
\end{tabular}


representing 9 daily feed intake per group ( 9 cage * 3 types of feed). For the 3rd month, we have 18 cages ( 6 cages *3 types of feed), and 9 cages for the 6th month (3 cages*3 types of feed). The equations are shown below.

Daily feed intake for each week $=$ weekly feed intake per cage $/(7 *$ number of mice $)$

The daily feed intake per mouse for each period $(1,3$, 6 months) was calculated as:

Daily feed intake $=$ accumulative feed intake per cage $/($ number of days $*$ number of mice $)$

\section{Intestinal permeability assessment}

The permeability of the intestinal barrier was evaluated by detecting the levels of lipopolysaccharides (LPS) and Dlactate and the activity of diamine oxidase (DAO) in serum. Four samples from each group were randomly chosen for these tests. The LPS content was measured using the ToxinSensor $^{\text {rix }}$ Chromogenic LAL Endotoxin Assay Kit (GenScript, USA). The D-lactate level was determined by the colorimetric method according to the manufacturer's protocol (D-lactate Assay Kit, BioVision, USA). The DAO activity was assessed by the reaction of cadaverine dihydrochloride (Sigma, USA) as described in our previous work [22].

\section{Histopathological and TEM observation of gut tissues}

For pathological assessment, all histopathological examinations were performed following a standard laboratory procedure. The intestinal tissues (three samples per group) were opened longitudinally and fixed in $10 \%$ formalin and embedded in paraffin blocks, from which $5 \mu \mathrm{m}$ thick samples were sliced and placed onto glass slides. The slices were stained with hematoxylin and eosin (HE), an optical microscope was used to observe and take pictures. The identity of the slides was blinded to the pathologist. Five intact villi were randomly chosen from each slide if available, the villi height and the crypt depth were measured in duodenum, jejunum and ileum to calculate the ratio of the villi height to the crypt depth, resulting in 15 intact villi being examined per group from the three slides. In case of intact villi are insufficient, five intact villi were counted for the group from the three slides.

For TEM observation, the ileal mucosa samples from control, $\mathrm{TiO}_{2} \mathrm{NPs}$ and $\mathrm{TiO}_{2}$ MPs group (one sample per group by the 6 th month) were cut into small pieces (surface area $=1^{*} 1 \mathrm{~mm}^{2}$ ) and immediately fixed in $2.5 \%$ glutaraldehyde ( $\mathrm{pH}=7.4)$ overnight. Then the samples were treated according to general protocols for TEM examination. The ultra-thin sections $(70-100 \mathrm{~nm})$ were stained with lead citrate and uranyl acetate and then were examined using a transmission electron microscopy (TEM, JEM-1400, JEOL, Japan).

\section{Titanium content analysis}

The blood cells were taken out and thawed (five samples per group).All the samples were freeze-dried in a freeze dryer (FD-1, Beijing Detianyou Technology Development Co., Ltd) with apparatus at $-50{ }^{\circ} \mathrm{C}$ and a pressure of $1.0 \mathrm{~Pa}$ for $24 \mathrm{~h}$, these samples weighed between $0.03-0.18 \mathrm{~g}$ after drying. The freeze-dried samples were digested in $2 \mathrm{~mL}$ nitric acid and $0.5 \mathrm{ml} \mathrm{H} \mathrm{H}_{2} \mathrm{O}_{2}$ overnight. After adding $1 \mathrm{~mL}$ $\mathrm{HF}$, the mixed solutions were heated at about $160^{\circ} \mathrm{C}$ using high-pressure reaction container in an oven chamber until the samples were completely digested. Then, the solutions were heated at $120^{\circ} \mathrm{C}$ to remove the remaining nitric acid until the solutions were colorless and clear. At last, the remaining solutions were diluted to $5 \mathrm{~mL}$ with $2 \%$ nitric acid and then were loaded onto an ICP-MS (NexION 300D, PerkinElmer) to analyze $\mathrm{Ti}$ concentration in the samples. The detection limit of $\mathrm{Ti}$ was $1.1 \mu \mathrm{g} / \mathrm{g}$. Concentrations of $\mathrm{Ti}$ element were expressed as milligrams per gram dried weight.

\section{Western blot analysis}

The ileum tissue samples (three samples per group) were lysed in radioimmunoprecipitation assay buffer (RIPA buffer) supplemented with a cocktail of protease inhibitors. Then the proteins were collected after centrifugation and quantified using a Bradford protein assay kit (Beyotime Biotechnology, China). Equal amount of protein was denatured and separated on $7-12 \%$ SDS-PAGE gels and then transferred to nitrocellulose membrane (Merckmillipore). The membranes were blocked with $5 \%$ skimmed milk, subsequently incubated with primary antibodies against ZO-1 (1:2000, Abcam), occludin (1: 20000, Abcam), and $\beta$-actin (1:30000) overnight at $4{ }^{\circ} \mathrm{C}$, and then incubated with secondary antibody for $2 \mathrm{~h}$ at room temperature. The protein bands were detected by Western Blotting Luminol Reagent (Absin Bioscience Inc., China) and recorded on Kodak films (Eastman Kodak Company, US). Relative band densities of the various proteins were measured from scanned films using Image J Software.

\section{Inflammatory cytokine analysis}

The concentrations of six cytokine biomarkers in sera and the ileum tissues (four samples per group) were analyzed using Milliplex Map Kit (Cat. No. MTH17MAG-47 K, Merck Millipore, USA) following the manufacturer's instructions. Briefly, the ileum tissues were homogenized in PBS buffer containing the protease inhibitors, then the supernatant was obtained after centrifugation. The tissue supernatants and sera samples, buffers, and cytokine standards were added into 96-well assay plates and incubated overnight at $4{ }^{\circ} \mathrm{C}$ with 
fluorescently labeled antibodies-coated beads which can capture IL-1 $\beta$, IL-6, IL-10, IL-13, TNF- $\alpha$, and IFN- $\gamma$. After further incubation with biotin-labelled detection antibodies and streptavidin-phycoerythrin conjugate, the beads were detected on a MAGPIX ${ }^{\oplus}$ multiplexing instrument (Luminex Corporation, USA). The xPONENT 4.1 software was used for data acquisition, with the calibration curve for each cytokine generated with a fiveparameter logistic fit. The detection limits for the cytokine assays were $1 \mathrm{pg} / \mathrm{mL}$.

\section{Statistical analysis}

SPSS 20.0 was used to carry out the statistical analysis. Data exhibited a normal distribution according to the K-S test were expressed as mean \pm standard deviation (SD). Independent-samples $\mathrm{T}$ test was used to assess the significant difference between two experimental groups. Oneway variance (ANOVA) with LSD-t or Dunnett's T3 tests was applied to evaluate the statistical significance of the differences between the experimental groups and the controls. The interaction between $\mathrm{TiO}_{2}$ and LPS were analyzed based on $2 \times 2$ factorial design analysis. A $p$ value less than 0.05 was considered statistically significant.

\section{Supplementary Information}

The online version contains supplementary material available at https://doi. org/10.1186/s12989-021-00399-x.

Additional file 1 Table S1. Impurity elements of $\mathrm{TiO}_{2} \mathrm{NPS}_{\text {and }} \mathrm{TiO}_{2} \mathrm{MPs}$ $(\mu \mathrm{g} / \mathrm{g})$

\section{Abbreviations}

TEM: transmission electron microscopy; XRD: X-ray powder diffractometry; BET: Brunauer-Emmett-Teller; ICP-MS: inductively coupled plasma mass spectrometry; AGJ: artificial gastric juice; AIJ: artificial intestinal juice; PDI: polydispersity index value; LPS: lipopolysaccharides; DAO: diamine oxidase; HE: hematoxylin and eosin

\section{Acknowledgements}

Not applicable.

\section{Authors' contributions}

Y.Z. designed the present study, performed all experiments and wrote manuscript. S.D. assisted in animal experiments. Y.L. assisted in interpretation of data. Y.W. conceived the present study, provided overall guidance to the development of the whole study, critically reviewed and revised the manuscript. All authors read and approved the final manuscript.

\section{Funding}

This work was supported by the National Natural Science Foundation of China (31971313, 31400863), the National Basic Research Program of China (2017YFC1600200), and the Beijing Natural Science Foundation (7172116).

\section{Availability of data and materials}

The datasets used and/or analyzed during the current study are available from the corresponding author on reasonable request.

\section{Ethics approval and consent to participate}

All animal procedures were approved by the Peking University Institutional Review Board.
Consent for publication

Not applicable.

\section{Competing interests}

The authors declare that they have no competing interests.

\section{Author details}

${ }^{1}$ Department of Occupational and Environmental Health Sciences, School of Public Health, Peking University, Beijing 100191, People's Republic of China.

${ }^{2}$ CAS Key Laboratory for Biomedical Effects of Nanomaterials and Nanosafety \& CAS Center for Excellence in Nanoscience, National Center for Nanoscience and Technology of China, Beijing 100190, People's Republic of China.

Received: 8 January 2020 Accepted: 17 January 2021

Published online: 17 February 2021

\section{References}

1. Peters RJ, van Bemmel G, Herrera-Rivera Z, Helsper HP, Marvin HJ, Weigel S, et al. Characterization of titanium dioxide nanoparticles in food products: analytical methods to define nanoparticles. J Agric Food Chem. 2014;62(27): 6285-93.

2. Lomer MCE, Hutchinson C, Volkert S, Greenfield SM, Catterall A, Thompson $\mathrm{RPH}$, et al. Dietary sources of inorganic microparticles and their intake in healthy subjects and patients with Crohn's disease. Brit J Nutr. 2004;92(6): 947-55.

3. Food, Ministry Of Agriculture Fisheries. Dietary intake of food additive in the UK: Initial surveillance (Food surveillance paper no.37). 1st ed. London: H.M. Stationery Office1993.

4. Yang $Y$, Doudrick K, Bi X, Hristovski $K$, Herckes $P$, Westerhoff $P$, et al. Characterization of food-grade titanium dioxide: the presence of nanosized particles. Environ Sci Technol. 2014;48(11):6391-400.

5. Weir A, Westerhoff P, Fabricius L, Hristovski K, von Goetz N. Titanium dioxide nanoparticles in food and personal care products. Environ Sci Technol. 2012:46(4):2242-50.

6. Chen XX, Cheng B, Yang YX, Cao AN, Liu JH, Du LJ, et al. Characterization and preliminary toxicity assay of Nano-titanium dioxide additive in sugarcoated chewing gum. Small. 2013;9(9-10):1765-74.

7. Farquhar MG, Palade GE. Junctional complexes in various epithelia. J Cell Biol. 1963;17(2):375-412.

8. Raleigh DR, Boe DM, Yu D, Weber CR, Marchiando AM, Bradford EM, et al. Occludin $\$ 408$ phosphorylation regulates tight junction protein interactions and barrier function. J Cell Biol. 2011;193(3):565-82.

9. Shen $L$, Weber $C R$, Raleigh DR, Yu D, Turner JR. Tight junction pore and leak pathways: a dynamic duo. Annu Rev Physiol. 2011;73:283-309.

10. Van Itallie CM, Fanning AS, Bridges A, Anderson JM. ZO-1 stabilizes the tight junction solute barrier through coupling to the Perijunctional cytoskeleton. Mol Biol Cell. 2009:20(17):3930-40.

11. Suzuki T, Yoshinaga N, Tanabe S. Interleukin-6 (IL-6) regulates claudin-2 expression and tight junction permeability in intestinal epithelium. J Biol Chem. 2011;286(36):31263-71.

12. Buschmann MM, Shen $L$, Rajapakse $H$, Raleigh DR, Wang $Y$, Wang $Y$, et al. Occludin OCEL-domain interactions are required for maintenance and regulation of the tight junction barrier to macromolecular flux. Mol Biol Cell. 2013:24(19):3056-68.

13. Wisner DM, Harris LR, Green $C L$, Poritz LS. Opposing regulation of the tight junction protein claudin-2 by interferon-gamma and interleukin-4. J Surg Res. 2008;144(1):1-7.

14. Mankertz J, Amasheh M, Krug SM, Fromm A, Amasheh S, Hillenbrand B, et al. TNFalpha up-regulates claudin-2 expression in epithelial HT-29/B6 cells via phosphatidylinositol-3-kinase signaling. Cell Tissue Res. 2009; 336(1):67-77

15. Turner JR. Intestinal mucosal barrier function in health and disease. Nat Rev Immunol. 2009:9(11):799-809.

16. MacNicoll A, Kelly M, Aksoy H, Kramer E, Bouwmeester H, Chaudhry Q. A study of the uptake and biodistribution of nano-titanium dioxide using in vitro and in vivo models of oral intake. J Nanopart Res. 2015; 17(2).

17. Wang J, Zhou G, Chen C, Yu H, Wang T, Ma Y, et al. Acute toxicity and biodistribution of different sized titanium dioxide particles in mice after oral administration. Toxicol Lett. 2007;168(2):176-85. 
18. Cho WS, Kang BC, Lee JK, Jeong J, Che JH, Seok SH. Comparative absorption, distribution, and excretion of titanium dioxide and zinc oxide nanoparticles after repeated oral administration. Part Fibre Toxicol. 2013;10:9.

19. Onishchenko GE, Erokhina MV, Abramchuk SS, Shaitan KV, Raspopov RV, Smirnova W, et al. Effects of Titanium Dioxide Nanoparticles on Small Intestinal Mucosa in Rats. B Exp Biol Med+. 2012;154(2):265-70.

20. Faust JJ, Doudrick K, Yang Y, Westerhoff P, Capco DG. Food grade titanium dioxide disrupts intestinal brush border microvilli in vitro independent of sedimentation. Cell Biol Toxicol. 2014;30(3):169-88.

21. Koeneman BA, Zhang Y, Westerhoff P, Chen YS, Crittenden JC, Capco DG. Toxicity and cellular responses of intestinal cells exposed to titanium dioxide. Cell Biol Toxicol. 2010;26(3):225-38.

22. Wang Y, Chen Z, Ba T, Pu J, Chen T, Song Y, et al. Susceptibility of young and adult rats to the oral toxicity of titanium dioxide nanoparticles. Small. 2013;9(9-10):1742-52.

23. Nogueira CM, de Azevedo WM, Dagli ML, Toma SH, Leite AZ, Lordello ML, et al. Titanium dioxide induced inflammation in the small intestine. World J Gastroenterol. 2012;18(34):4729-35.

24. Clayburgh DR, Musch MW, Leitges M, Fu YX, Turner JR. Coordinated epithelial NHE3 inhibition and barrier dysfunction are required for TNFmediated diarrhea in vivo. J Clin Invest. 2006;116(10):2682-94.

25. Clayburgh DR, Barrett TA, Tang YM, Meddings JB, Van Eldik LJ, Watterson DM, et al. Epithelial myosin light chain kinase-dependent barrier dysfunction mediates T cell activation-induced diarrhea in vivo. J Clin Invest. 2005; 115(10):2702-15.

26. Wang FJ, Graham WV, Wang YM, Witkowski ED, Schwarz BT, Turner JR. Interferon-gamma and tumor necrosis factor-alpha synergize to induce intestinal epithelial barrier dysfunction by up-regulating myosin light chain kinase expression. Am J Pathol. 2005;166(2):409-19.

27. Utech M, Ivanov Al, Samarin SN, Bruewer M, Turner JR, Mrsny RJ, et al. Mechanism of IFN-gamma-induced endocytosis of tight junction proteins: myosin II-dependent vacuolarization of the apical plasma membrane. Mol Biol Cell. 2005;16(10):5040-52

28. Al-Sadi R, Ye D, Dokladny K, Ma TY. Mechanism of IL-1 beta-induced increase in intestinal epithelial tight junction permeability. J Immunol. 2008;180(8): 5653-61.

29. Powell JJ, Harvey RS, Ashwood P, Wolstencroft R, Gershwin ME, Thompson RP. Immune potentiation of ultrafine dietary particles in normal subjects and patients with inflammatory bowel disease. J Autoimmun. 2000;14(1):99-105.

30. Huang C, Sun MY, Yang Y, Wang F, Ma XQ, Li JQ, et al. Titanium dioxide nanoparticles prime a specific activation state of macrophages. Nanotoxicology. 2017;11(6):737-50.

31. Duan YM, Liu J, Ma LL, Li N, Liu HT, Wang J, et al. Toxicological characteristics of nanoparticulate anatase titanium dioxide in mice. Biomaterials. 2010;31(5):894-9.

32. Hu HL, Guo Q, Wang CL, Ma X, He HJ, Oh YR, et al. Titanium dioxide nanoparticles increase plasma glucose via reactive oxygen species-induced insulin resistance in mice. J Appl Toxicol. 2015;35(10):1122-32.

33. Chen ZJ, Wang Y, Ba T, Li Y, Pu J, Chen T, et al. Genotoxic evaluation of titanium dioxide nanoparticles in vivo and in vitro. Toxicol Lett. 2014;226(3):314-9.

34. Chen Z, Wang Y, Zhuo L, Chen S, Zhao L, Chen T, Li Y, Zhang W, Gao X, Li $P$, Wang $H$, Jia $G$. Interaction of titanium dioxide nanoparticles with glucose on young rats after oral administration. Nanomedicine. 2015;11(7):1633-42.

35. Rodriguez-Escamilla JC, Medina-Reyes El, Rodriguez-lbarra C, Deciga-Alcaraz A, Flores-Flores JO, Ganem-Rondero A, et al. Food-grade titanium dioxide (E171) by solid or liquid matrix administration induces inflammation, germ cells sloughing in seminiferous tubules and blood-testis barrier disruption in mice. J Appl Toxicol. 2019;39(11):1586-605.

36. Dorier M, Beal D, Marie-Desvergne C, Dubosson M, Barreau F, Houdeau E, et al. Continuous in vitro exposure of intestinal epithelial cells to E171 food additive causes oxidative stress, inducing oxidation of DNA bases but no endoplasmic reticulum stress. Nanotoxicology. 2017;11(6):751-61.

37. Gao $Y$, Ye $Y$, Wang J, Zhang $H$, Wu $Y$, Wang $Y$, et al. Effects of titanium dioxide nanoparticles on nutrient absorption and metabolism in rats: distinguishing the susceptibility of amino acids, metal elements, and glucose. Nanotoxicology. 2020;14(10):1301-23.

38. Song ZM, Chen N, Liu JH, Tang H, Deng X, Xi WS, et al. Biological effect of food additive titanium dioxide nanoparticles on intestine: an in vitro study. J Appl Toxicol. 2015;35(10):1169-78.
39. Vila L, Garcia-Rodriguez A, Marcos R, Hernandez A. Titanium dioxide nanoparticles translocate through differentiated Caco-2 cell monolayers, without disrupting the barrier functionality or inducing genotoxic damage. J Appl Toxicol. 2018;38(9):1195-205.

40. Duan S-M, Zhang Y-L, Gao Y-J, Lv L-Z, Wang Y. The influence of long-term dietary intake of titanium dioxide particles on elemental homeostasis and tissue structure of mouse organs. J Nanosci Nanotechnol. in press.

41. Shakiba S, Hakimian A, Barco LR, Louie SM. Dynamic intermolecular interactions control adsorption from mixtures of natural organic matter and protein onto titanium dioxide nanoparticles. Environ Sci Technol. 2018;52(24):14158-68.

42. Barbero F, Russo L, Vitali M, Piella J, Salvo I, Borrajo ML, et al. Formation of the protein Corona: the Interface between nanoparticles and the immune system. Semin Immunol. 2017;34(C):52-60.

43. Sinnecker $\mathrm{H}$, Ramaker K, Frey A. Coating with luminal gut-constituents alters adherence of nanoparticles to intestinal epithelial cells. Beilstein J Nanotechnol. 2014;5:2308-15.

44. Talbot P, Radziwill-Bienkowska JM, Kamphuis JBJ, Steenkeste K, Bettini S, Robert $V$, et al. Food-grade TiO2 is trapped by intestinal mucus in vitro but does not impair mucin O-glycosylation and short-chain fatty acid synthesis in vivo: implications for gut barrier protection. J Nanobiotechnol. 2018;16(1):53.

45. van Wettere WHEJ, Willson NL, Pain SJ, Forder REA. Effect of oral polyamine supplementation pre-weaning on piglet growth and intestinal characteristics. Animal. 2016;10(10):1655-9.

46. Moeser AJ, Ryan KA, Nighot PK, Blikslager AT. Gastrointestinal dysfunction induced by early weaning is attenuated by delayed weaning and mast cell blockade in pigs. Am J Physiol-Gastr L. 2007;293(2):G413-G21.

47. Xiong X, Yang HS, Wang XC, Hu Q, Liu CX, Wu X, et al. Effect of low dosage of chito-oligosaccharide supplementation on intestinal morphology, immune response, antioxidant capacity, and barrier function in weaned piglets. J Anim Sci. 2015;93(3):1089-97.

48. Ammendolia MG, losi F, Maranghi F, Tassinari R, Cubadda F, Aureli F, et al. Short-term oral exposure to low doses of nano-sized TiO2 and potential modulatory effects on intestinal cells. Food Chem Toxicol. 2017;102:63-75.

49. Bettini S, Boutet-Robinet E, Cartier C, Comera C, Gaultier E, Dupuy J, et al. Food-grade $\mathrm{TiO} 2$ impairs intestinal and systemic immune homeostasis, initiates preneoplastic lesions and promotes aberrant crypt development in the rat colon. Sci Rep. 2017:7:40373.

50. Garcia-Rodriguez A, Vila L, Cortes C, Hernandez A, Marcos R. Effects of differently shaped TiO(2)NPs (nanospheres, nanorods and nanowires) on the in vitro model (Caco-2/HT29) of the intestinal barrier. Part Fibre Toxicol. 2018;15(1):33.

51. Riedle S, Pele LC, Otter DE, Hewitt RE, Singh H, Roy NC, et al. Proinflammatory adjuvant properties of pigment-grade titanium dioxide particles are augmented by a genotype that potentiates interleukin 1 beta processing. Part Fibre Toxicol. 2017; 14(1):51.

52. Bianchi MG, Allegri M, Chiu M, Costa AL, Blosi M, Ortelli $S$, et al. Lipopolysaccharide adsorbed to the bio-Corona of $\mathrm{TiO} 2$ nanoparticles powerfully activates selected pro-inflammatory transduction pathways. Front Immunol. 2017:8:866

53. Gao Y, Li T, Duan S, Lyu L, Li Y, Xu L, Wang Y. Impact of titanium dioxide nanoparticles on intestinal community in 2,4,6-trinitrobenzenesulfonic acid (TNBS)-induced acute colitis mice and the intervention effect of vitamin $E$. Nanoscale. 2021. https://doi.org/10.1039/d0nr08106j.

\section{Publisher's Note}

Springer Nature remains neutral with regard to jurisdictional claims in published maps and institutional affiliations.

\section{Ready to submit your research? Choose BMC and benefit from:}

- fast, convenient online submission

- thorough peer review by experienced researchers in your field

- rapid publication on acceptance

- support for research data, including large and complex data types

- gold Open Access which fosters wider collaboration and increased citations

- maximum visibility for your research: over $100 \mathrm{M}$ website views per year

At $\mathrm{BMC}$, research is always in progress.

Learn more biomedcentral.com/submissions 